\title{
INTEGRATING GEOLOGICAL MAPPING AND GEOPHYSICAL ANALYSES IN SOUTHERN ESPINHAÇO RANGE, EASTERN EDGE OF THE SÃO FRANCISCO CRATON, BRAZIL
}

\author{
William Medina Leite Féres (D) 1 , Pedro Ângelo Almeida Abreu(D) ${ }^{2}$ and Wilbor Poletti (D)
}

\begin{abstract}
The São Francisco Craton is one of the fundamental pieces on the evolutionary history of the Gondwana supercontinent. At its southeast edge, the Southern Espinhaço Range (SER) is built mainly by Paleo- and Mesoproterozoic units of the Espinhaço Supergroup. At its western domain, one of its major components, the Conselheiro Mata Group, occurs as a relatively narrow strip, being composed by a succession of formations related to coastal and shallow marine environments. Aiming to present and discuss an integrated research, detailed fieldwork was carried out, gamma-ray spectrometry data were reprocessed, and ground gravity data were acquired. This integration allows clarifying the regional crustal structure and the general geometry of the Espinhaço basin. The defined gamma-ray spectrometry domains fit well to the lithological types and structural framework of the stratigraphic units. Bouguer residual anomaly highlights an amplitude of $27 \mathrm{mGal}$, ranging from -12 to $15 \mathrm{mGal}$, outlining a gravity compartmentation defined by a central negative anomaly (CNA) surrounded by positive anomalies, which is approximately in conformity with the regional tectonic segments. The CNA conforms to the main axis of SER, indicating the residual metasedimentary coverage of the Espinhaço basin. Its center, positioned above the Lamarão anticline, houses the nucleus of the precursor basin of Conselheiro Mata Group.
\end{abstract}

Keywords: gravimetry; Espinhaço Supergroup; Conselheiro Mata Group.

RESUMO. O Cráton São Francisco é uma das peças fundamentais da história evolutiva do Supercontinente Gondwana. Em sua borda sudeste, a Serra do Espinhaço Meridional é formada, principalmente, por unidades Paleoa Mesoproterozoicas do Supergrupo Espinhaço. Um de seus principais componentes, o Grupo Conselheiro Mata, ocorre como uma faixa relativamente estreita no domínio ocidental da serra, sendo composto por uma sucessão de formações relacionadas a ambientes marinhos rasos e costeiros. Com o objetivo de apresentar e discutir uma pesquisa integrada, foram realizados trabalho de campo detalhado, processamento de dados gamaespectrométricos e aquisição de dados gravimétricos terrestres. Tal integração permite esclarecer a estrutura crustal regional e a geometria geral da bacia Espinhaço. Os domínios gamaespectrométricos definidos ajustam-se bem às litologias e ao arcabouço estrutural das unidades estratigráficas. Anomalias Bouguer residuais demonstram uma amplitude de 27 $\mathrm{mGal}$, variando entre -12 a $15 \mathrm{mGal}$, concordando aproximadamente com os segmentos tectônicos regionais e esboçando uma compartimentação gravimétrica definida por uma anomalia negativa central (CNA), cercada por anomalias positivas. A CNA concorda com o eixo principal da Serra do Espinhaço Meridional, definindo a cobertura metassedimentar residual da bacia Espinhaço. Seu centro, posicionado sobre o anticlinal do Lamarão, abriga o núcleo da bacia precursora do Grupo Conselheiro Mata.

Palavras-chave: gravimetria; Supergrupo Espinhaço; Grupo Conselheiro Mata.

Corresponding author: William Medina Leite Féres

1Jaguar Mining Inc., Fazenda Brumado s/n - 35960-000 - Santa Bárbara, MG, Brazil - E-mail: williammedinaleite@gmail.com 2Universidade Federal dos Vales do Jequitinhonha e Mucuri - Campus JK, CeGeo, Instituto de Ciência e Tecnologia, Rodovia BR-367, km 583, n5 5000 - 39100-000 - Alto da Jacuba, Diamantina, MG, Brazil - E-mails: pangelo.ufvjm@gmail.com, wilbor.polett@@ict.ufvjm.edu.br 


\section{INTRODUCTION}

The São Francisco Craton (SFC) consists of a large and stable part of the Brazilian shield, integrating itself with the group of fundamental pieces on the evolutionary history of the Gondwana supercontinent (Heilbron et al., 2017; D'AgrelaFilho \& Cordani, 2017). At the southeast edge of the SFC, there is a mountain range with continental dimension ( 1,200 km long), called Espinhaço range, which extends geographically across the states of Minas Gerais and Bahia. The southern segment of this mountain is located at the outer part of Araçuaí Belt (Almeida, 1977) - later named as Araçuaí Orogen (Pedrosa-Soares et al., 2007). The Southern Espinhaço Range (SER) is built mainly by Paleo- and Mesoproterozoic units of the Espinhaço Supergroup and bordered by rocks of the Macaúbas Group, while the adjacent cratonic domains are covered by the Neoproterozoic units of the Bambuí Group.

The Espinhaço basin was responsible for accommodating the homonymous Supergroup (i.e., Espinhaço Supergroup). Regarding the evolution of its basin, some authors argue that after breakup this structure experienced an entire Wilson Cycle, namely, the crustal distension followed by rifting and evolving to a passive continental margin, that was inverted by a subsequent Mesoproterozoic orogeny (Herrgesell \& Pflug, 1986; Knauer, 1990; Almeida-Abreu, 1995; Almeida-Abreu \& Renger, 2007). Other authors suggested that the Espinhaço basin developed entirely in an intracratonic context, admitting a tectonic-sedimentary evolution model as a rift-sag basin (Martins-Neto, 1998), that remained under tectonic quiescence until the end of Neoproterozoic, being affected only by Brazilian tectonism (Uhlein et al., 1986; Dossin et al.,1990; Dussin \& Dussin, 1995; Chemale Jr. et al., 2012).

The Conselheiro Mata Group (CMG) integrates the Espinhaço Supergroup. The CMG occurs as a relatively narrow strip in the western domain of the SER, being composed of a succession of formations related to coastal and shallow marine environments. The CMG also has a controversial origin in terms of its tectonic environment and basin evolution. Some authors considered the CMG as the record of a thermalflexural subsidence phase of the Espinhaço basin, in response to the thermal contraction of the lithosphere during its cooling (e.g., Martins-Neto, 1998; Martins-Neto et al., 2001). On the other hand, some researchers considered the deposition of CMG as consequence of the thermal contraction of the basin in a post-rift phase (Almeida-Abreu, 1993, 1995); or as a foredeep basin resulting from the isostatic response to tectonic stacking given by the $\mathrm{W}$-vergent thrusts during the Espinhaço orogeny (Almeida-Abreu et al., 2001; Almeida-Abreu \& Renger, 2002, 2007).

Pioneering works on the geology of SER have been developed since the $17^{\text {th }}$ century, especially from publications put forward by Eschwege (1822), Derby (1906), Moraes \& Guimarães (1930) and Barbosa (1951), that supported the proposals on SER stratigraphy (see Pflug \& Renger, 1973; Renger, 1979; Renger \& Knauer, 1995). In the second half of the $20^{\text {th }}$ century, a revolution in knowledge about SER geology came with the geological map of about 30 thousand $\mathrm{km}^{2}$ carried out by Pflug and collaborators (Pflug, 1965, 1968; Pflug \& Renger, 1973), and with the subsequent detailed studies on the geology of the region (Scholl \& Fogaça, 1979; Fogaça et al., 1984; AlmeidaAbreu \& Pflug, 1994; Dussin \& Dussin, 1995).

In view of the immense rock exposures in the region and the peculiar nature of SER geological evolution, R. Pflug turned this region into an enormous natural laboratory, making geoscience schools from different countries come to the region to carry out geological mapping works. However, if these approaches contributed to the increase in the volume of information on surface geology, on the other hand, knowledge about subsurface geology remained relatively restrict.

The first geophysical works in the southeast region of Minas Gerais approached the crust 
structure from gravity and seismic refraction data carried out by Blitzkow et al. (1979) and Giese \& Schütte (1980), respectively. More recent works of seismic reflection have contributed to recognizing deep unconformities, structural styles and stratigraphic successions of coverings of the edges and the central part of the São Francisco Craton (Romeiro-Silva \& Zalán, 2005; Hercos et al., 2007; Reis, 2011). In turn, between 2001 and 2013, the Minas Gerais Development Company (CODEMIG) provided a coverage of most of the state surface with magnetic and gamma-ray spectrometric airborne surveys, thus providing a substantial collection of geophysical data.

In this work we present a reassessment of gammaspectrometric data, new gravity data, and relate them to the surface geology of the northern part of SER. Additional field work was carried out to refine the geology, mainly the units of the CMG. The integration of geological and geophysical data allows visualizing the regional crustal structure, as well as the general geometry of the Espinhaço basin in the study area.

\section{Regional geology}

The Southern Espinhaço Range (SER) is built mainly by Paleo- to Mesoproterozoic rocks of the Espinhaço Supergroup (ESg) (Almeida-Abreu \& Renger, 2002). The stratigraphic stacking of the $\mathrm{ESg}$ was divided into eight formations by Pflug (1968), defined from bottom to top: São João da Chapada, Sopa-Brumadinho, Galho do Miguel, Santa Rita, Córrego dos Borges, Córrego Bandeira, Córrego Pereira, and Rio Pardo Grande. The first three formations were assembled in the Guinda Group (Knauer, 1990), which occupies most of SER. Metarenites and, subordinately, metapelites, metaconglomerates, and some metavolcanic rocks are the main lithologies of the Guinda Group.

The units of the Guinda Group are covering Archean rocks of the crystalline basement and, or Paleoproterozoic rocks of the Rio Paraúna
Supergroup (Fogaça et al., 1984), which emerge in structural windows in the central part of SER and vast areas of the SER eastern border. Almeida-Abreu \& Renger (2007) considered the units of the Guinda Group as deposits of an extensive and wide alluvial plain placed in the western vicinity of the Espinhaço marine basin.

The five superior formations of the ESg were brought together in the Conselheiro Mata Group (CMG) (Dossin et al., 1984), and characterized by alternating pelitic versus sandy units of shallow and coastal marine environments (Schöll \& Fogaça, 1979). These formations crop out exclusively in a narrow strip along the western edge of SER, as well as in Serra do Cabral (Fig. 1). Although it is narrow and elongated, the basin that accommodated the CMG shows, at its edges, convergent sedimentary flow. That is, on its western margin, sedimentary structures show flow to the east, while on its eastern border, sedimentary structures show flow to the west (Almeida-Abreu et al., 2001).

Dupont (1995) proposed that the CMG formations record a phase of tectonic stability in the Espinhaço basin with the installation of marine environments, and the evolution of the basin being marked by three major transgressive surfaces. Santos et al. (2015) proposed as a paleogeographic model for the CMG an alternation of transgressive-regressive cycles after a rifting in about $1.2 \mathrm{Gyr}$, which reactivated Statherian normal faults. A transition phase from mechanical to thermal subsidence preceded the alternation of deposition of pelitic sediments (during transgressive events) with sedimentation of sand deposits (regressive events).

The formations of the Guinda and Conselheiro Mata groups make up the orographic building of SER itself, however, throughout to the east of SER it can be found an outcrop of rocks of different natures that belong to ESg, especially rocks of sedimentary origin that were deposited in a supposed marine-oceanic basin (Pflug, 1965; Herrgesell \& Pflug, 1986; Almeida-Abreu \& Renger, 
2002, 2007). Four lithostratigraphic units represent the ESg on the eastern edge of SER, composed of metaultramafic rocks, iron formations, metapelites, metarenites and metaconglomerates, which were gathered together in the Serro Group by AlmeidaAbreu \& Renger (2007).

In the northeast of SER, there is a thick and continuous succession of greenschists and smaller intercalations of metapelites and quartzites, being covered by metarenites and metaconglomerates. The succession was divided into three formations by Chula et al. (1996), named Planalto de Minas (greenschists), Tapera (metapelites and greenschists), and Serra do Atalho (metarenites and metaconglomerates). These formations were brought together in the Desembargador Otoni Group by Almeida-Abreu \& Renger (2007). Considering the nature of the succession and the geochronological ages obtained in the igneous rocks, i.e., about $1.75 \mathrm{Gyr}$ (Machado et al., 1989; Hagedorn et al., 2003), it indicates that they are rocks related to the pre-rift phase of the Espinhaço basin (Chula et al., 1996; Almeida-Abreu \& Renger, 2007).

Units of ESg are covered by glaciogenic rocks from the Macaúbas Group, which occurs on vast areas of the northeast of SER (Fig. 1). In this area, glaciogenic rocks comprise metapelites (rhythmites, often with dropstones), with intercalations of metarenites (Fraga, 2013) and with massive diamictites (tillites) of varying thickness locally. Outcrops of tillites are abundant on the slopes and foothills of SER. Along the western edge of SER, around Serra do Cabral and in Serra da Água Fria, the rocks of the Macaúbas Group comprise, almost always, massive tillites of small thickness, forming fringes that outline the contour of the SER elevations (Fig. 1). The continuous distribution of tillites at the same altitude and seat on different units of the ESg indicates a pervasive angular and erosive unconformity (Köster, 1984; AlmeidaAbreu \& Renger, 2002). Considering that the glacial event occurred in $\sim 1.0 \mathrm{Ga}$ (Karfunkel \&
Hoppe, 1988, D'Agrella Filho et al., 1990), it was established that the Espinhaço orogeny occurred before the end of the Mesoproterozoic (AlmeidaAbreu \& Renger, 2007). This statement is also denoted by the basic rock dykes from Pedro Lessa Suite (906 \pm 2 Myr, Machado et al., 1989) (Fig. 1), which cover about $2.5 \%$ of SER surface (Hoppe, 1986) and intrude ESg rocks, cutting the tectonic structures molded in the lithologies of this supergroup.

The Bambuí Group covers vast areas of the SFC and, in the study area, outcrops in the cratonic domain (Fig. 1). Martins-Neto et al. (2001) admitted that Bambuí Group represents epicontinental deposits of a foreland basin related to the development of the Brasília belt orogeny in western edge of the SFC. Kuchenbecker (2011) included at the base of the Bambuí Group the Jequitaí and Carrancas formations, units deposited under glacial influence and considered to belong to the Macaúbas Group.

\section{METHODOLOGY}

In order to provide new data on the surface geology, detailed fieldwork was carried out and then incorporated into the available geological maps covering the study area (Köster, 1984; Noce, 1997a; Fogaça, 1997; Romano et al., 2014; Lopes et al., 2014). In addition, the gamma-ray spectrometry data were reprocessed (Prospectors, 2009; Lasa, 2009a) and ground gravity data have been acquired for an integrated visualization with surface geology data.

The main targets of the geological field data acquisition consisted in: i) to describe sections/profiles of structural and stratigraphic sequences; and ii) to provide physical characterization of rocks, including the measurements of tectonic structures and the observation of the nature of the contacts between lithologies and lithostratigraphic units. 


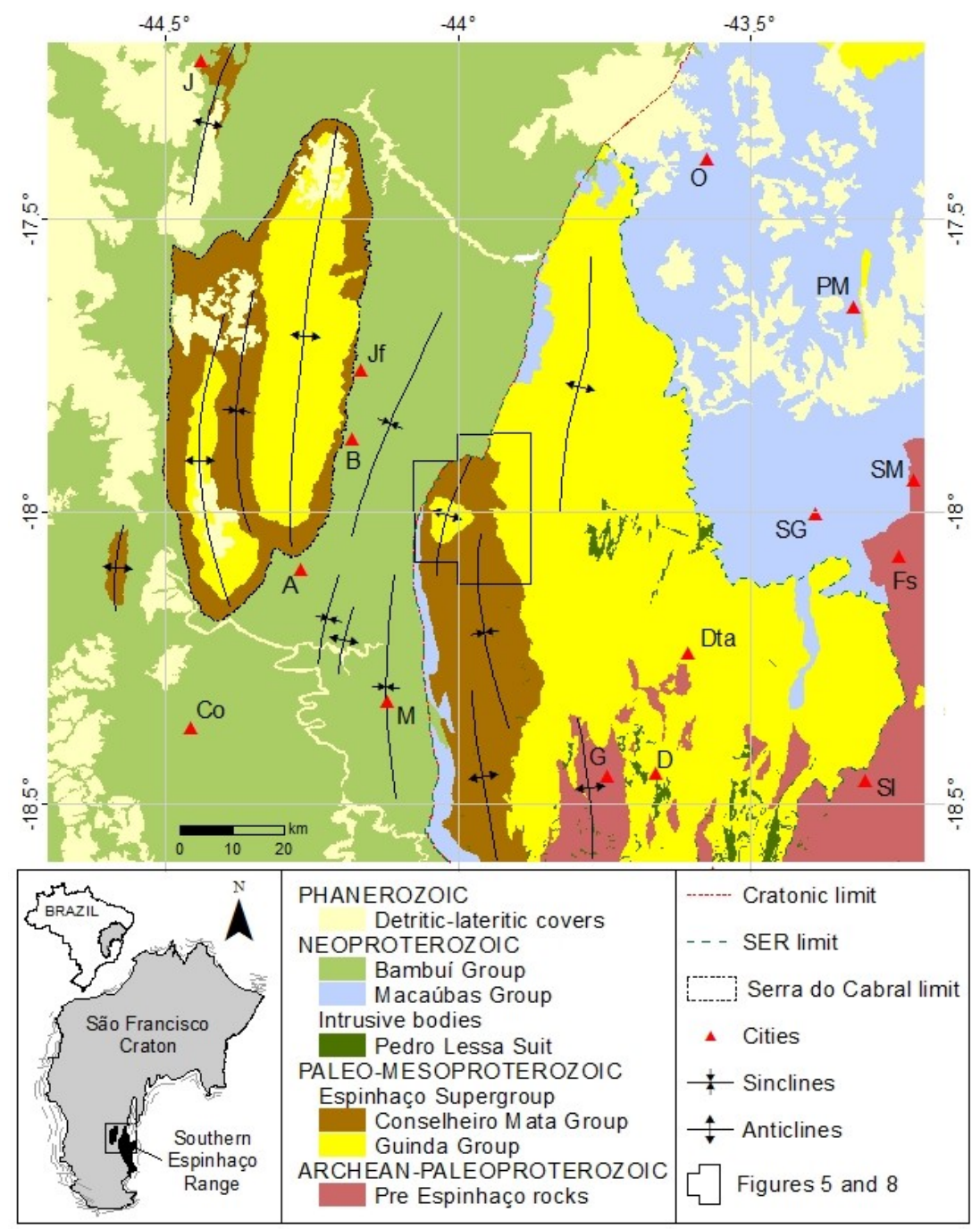

Figure 1 - Geological map of the Southern Espinhaço Range northern portion and Serra do Cabral (compiled and simplified by Noce, 1997a; Fogaça, 1997; Romano et al., 2014; Lopes et al., 2014). Cities: J: Jequitaí; O: Olhos D’água; PM: Planalto de Minas; Jf: Joaquim Felício; B: Buenópolis; SM: Senador Modestino Gonçalves; SG: São Gonçalo do Rio Preto; Fs: Felício dos Santos; A: Augusto de Lima; Dta: Diamantina; M: Monjolos; Co: Corinto; G: Gouveia; D: Datas; SI: Santo Antônio do Itambé.

The set of gamma-ray spectrometric data used in this work was provided by Minas Gerais Development Company (CODEMIG), acquired from the "Minas Gerais aero-geophysical survey program 2001/2013" (Megafísica, 2001a,b; Prospectors, 2009; Lasa, 2009a, 2009b, 2009c). The study area inserts itself in two distinct domains of this aerogeophysical program (Fig. 2A), that is, "survey 10" (carried out by Prospectors, 2009) and "survey 11a" (carried out by Lasa, 2009a), which followed the technical parameters presented in Table 1.
In the gamma-ray spectrometry dataset, filters were applied to produce a better knitting with surveys. Data processing started with a verification of anomalous values, the distribution and the amplitude of data intervals for each survey. To neutralize the difference among amplitudes of data ranges on the overlap zone between surveys, we applied the Hanning filter three times, followed by the trend filter (Grochowski et al, 2019). Then, it was made a suture grid knitting with surveys and each channel was clipped to the local study area. 


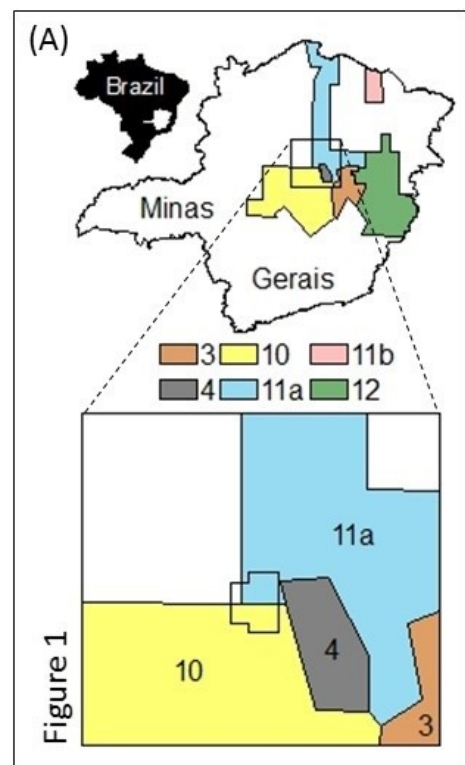

(B) Definition of database file for the search area (separate for each survey)
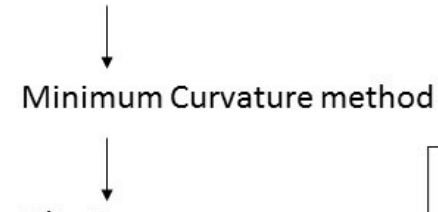

Filtering:

Hanning (3x) and Trend
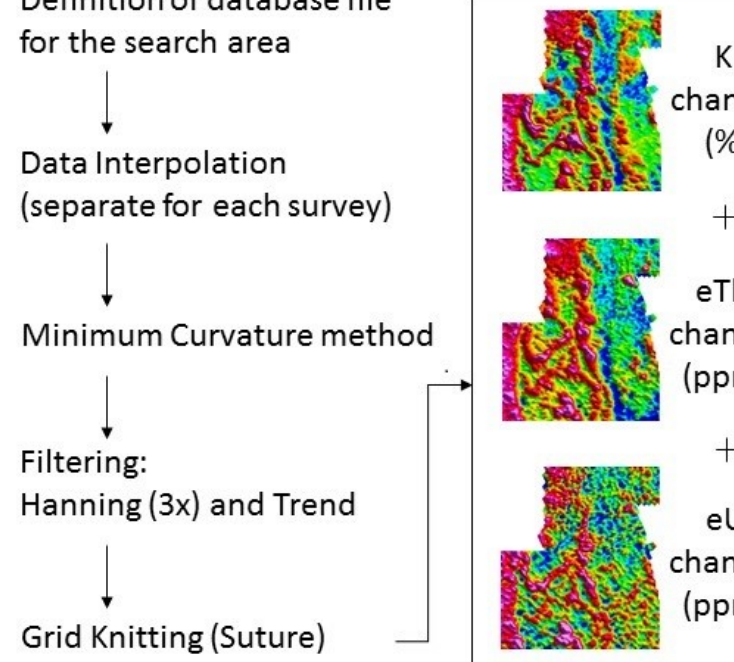
channe

(\%)
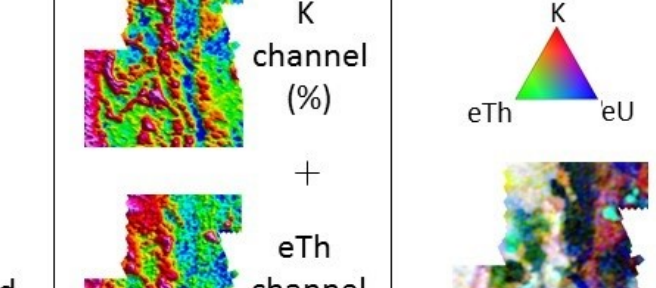

+
Th
anne (ppm)
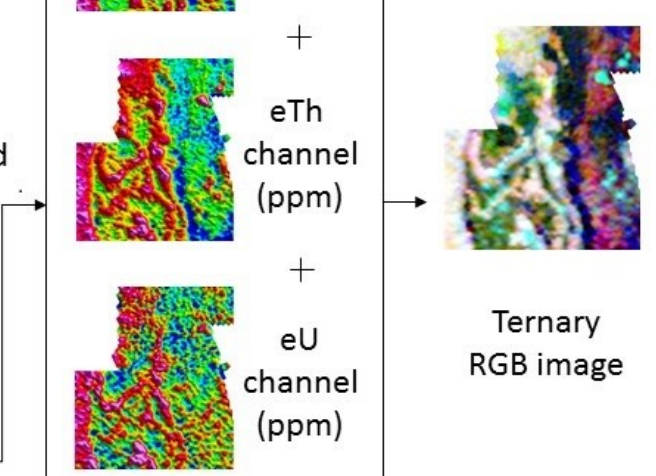

Ternary

RGB image

Figure 2 - (A) Location map of the aero-geophysical program indicating the link with survey 10 and survey 11a in the study area and $(B)$ the flowchart of geophysical data processing for gamma-ray spectrometry images.

Table 1 - Flight parameters for airborne geophysical data acquisition.

\begin{tabular}{|c|c|c|c|c|c|c|}
\hline Parameter & Survey 3 & Survey 4 & Survey 10 & Survey 11a & Survey 11b & Survey 12 \\
\hline Flight line direction & N30W & N20E & N-S & N25W & N25W & N30W \\
\hline Flight line spacing & $250 \mathrm{~m}$ & $250 \mathrm{~m}$ & $500 \mathrm{~m}$ & $500 \mathrm{~m}$ & $500 \mathrm{~m}$ & $500 \mathrm{~m}$ \\
\hline Control line direction & N60E & N70W & E-W & N65E & N65E & N60E \\
\hline Control line spacing & $2.5 \mathrm{~km}$ & $2.5 \mathrm{~km}$ & $10 \mathrm{~km}$ & $10 \mathrm{~km}$ & $10 \mathrm{~km}$ & $10 \mathrm{~km}$ \\
\hline Sampling rate & $1.0 \mathrm{~s}$ & $1.0 \mathrm{~s}$ & $1.0 \mathrm{~s}$ & $1.0 \mathrm{~s}$ & $1.0 \mathrm{~s}$ & $1.0 \mathrm{~s}$ \\
\hline Average flight height & $100 \mathrm{~m}$ & $100 \mathrm{~m}$ & $100 \mathrm{~m}$ & $100 \mathrm{~m}$ & $100 \mathrm{~m}$ & $100 \mathrm{~m}$ \\
\hline Approximate flight speed & $200 \mathrm{~km} / \mathrm{h}$ & $200 \mathrm{~km} / \mathrm{h}$ & $270 \mathrm{~km} / \mathrm{h}$ & $273 \mathrm{~km} / \mathrm{h}$ & $266 \mathrm{~km} / \mathrm{h}$ & $275 \mathrm{~km} / \mathrm{h}$ \\
\hline Acquisition date & 2001 & 2001 & 2009 & 2009 & 2009 & 2009 \\
\hline
\end{tabular}

Subsequently, a gamma-ray spectrometry map for each radioactive element $(\mathrm{K}$, eTh and $\mathrm{eU})$ and Ternary RGB image (R-K, G-eTh, B-eU) were generated. Data were interpolated using the minimum curvature method, from around 14,000 reading points. A grid of cells with a size of $125 \mathrm{~m}$ was created, which corresponds to $1 / 4$ of the flight line spacing for the surveys. Figure $2 \mathrm{~B}$ summarizes the flow of procedures described before, followed to generate the ternary RGB image from gamma-ray spectrometry data.
Ground gravity data were obtained using a differential gravimeter (CG-5 model, Scintrex Ltd.). Data from 652 stations were acquired, located in the north and northwest part of SER and adjacent domains, including Serra do Cabral (Fig. 3). The stations were lined up in profiles with spacing ranging from 1 to $6 \mathrm{~km}$. The gravity station of DatasMG (coordinates 18 $26^{\prime} 49^{\prime \prime} \mathrm{S}, \quad 43^{\circ} 39^{\prime} 31^{\prime \prime} \mathrm{W}$, 1,231.64 $\mathrm{m}$ altitude and $\mathrm{G}=978,202.15 \mathrm{mGal}$ ), registered by the Brazilian Institute of Geography and Statistics (IBGE), was used as reference to 


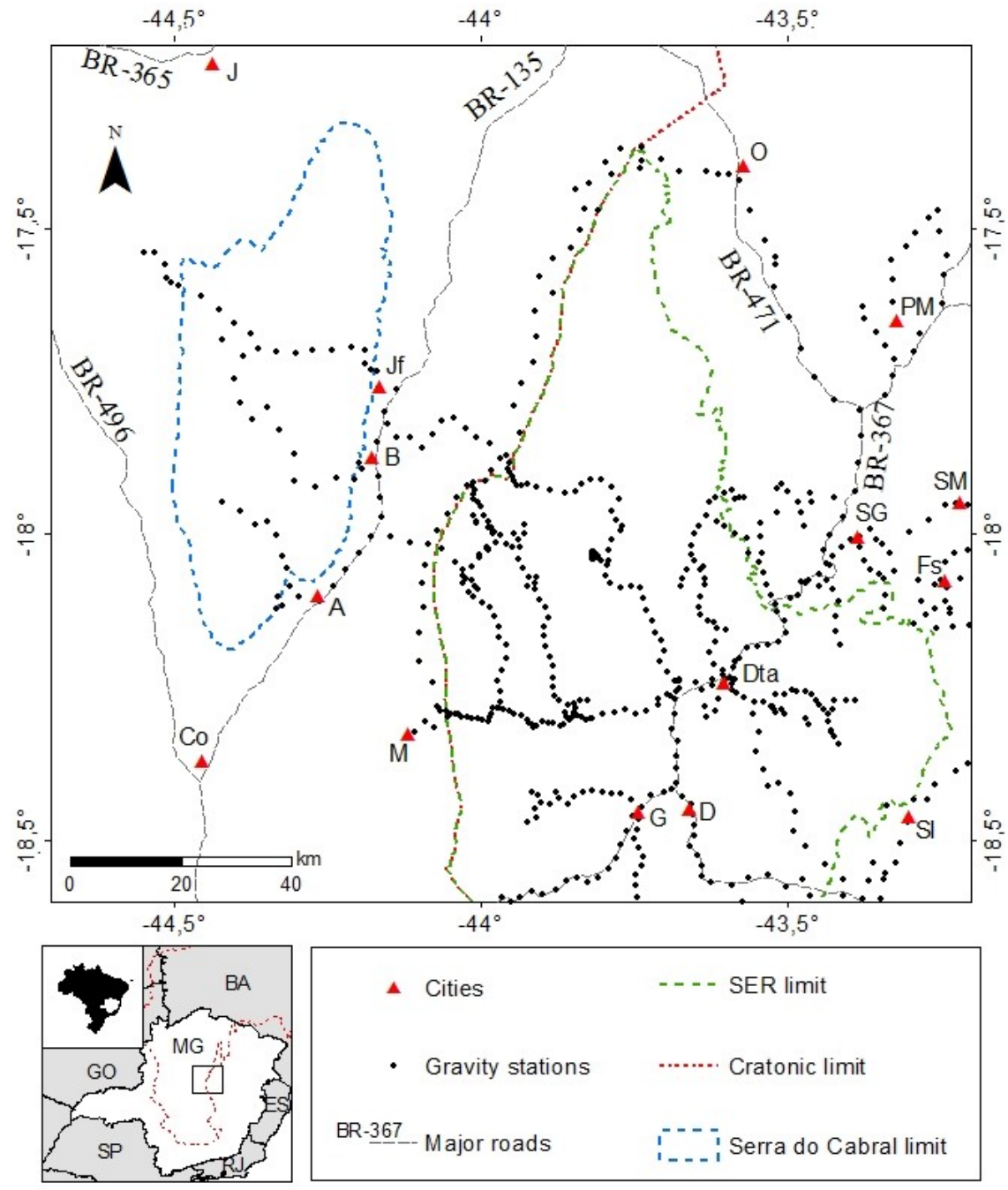

Figure 3 - Location of gravity stations acquired in relation to Minas Gerais state and São Francisco Craton limits. Same area as Figure 1.

calibrate the CG-5 gravimeter and thus to establish the absolute values of the gravitational field for each station.

Bouguer anomalies were obtained from gravity measurements of all stations following the methods proposed by Telford et al. (1990) and Kearey et al. (2002). The results were interpolated on surface maps using spline functions, with a smooth factor of 0.25 . To visualize the subsurface geological features, the residual map was estimated, obtained by subtracting long wavelength gravity anomaly from Bouguer anomaly map. The flowchart of Figure 4 shows the routine for acquiring and processing gravity data.

\section{RESULTS}

\section{Geological data}

In the study area the Galho do Miguel Formation of the Guinda Group outcrops, as well as all formations of the Conselheiro Mata Group. Younger rocks of the Macaúbas and Bambuí Groups lie on different units of the ESg around SER and Serra do Cabral (Figs. 1 and 5).

It was described 61 outcrops along the field work campaigns, and the data were integrated to the maps of Köster (1984), Noce (1997a), Fogaça (1997), Romano et al. (2014) and Lopes et al. (2014) (Fig. 5). In addition, four stratigraphic sections were raised (Figs. 6 and 7). 

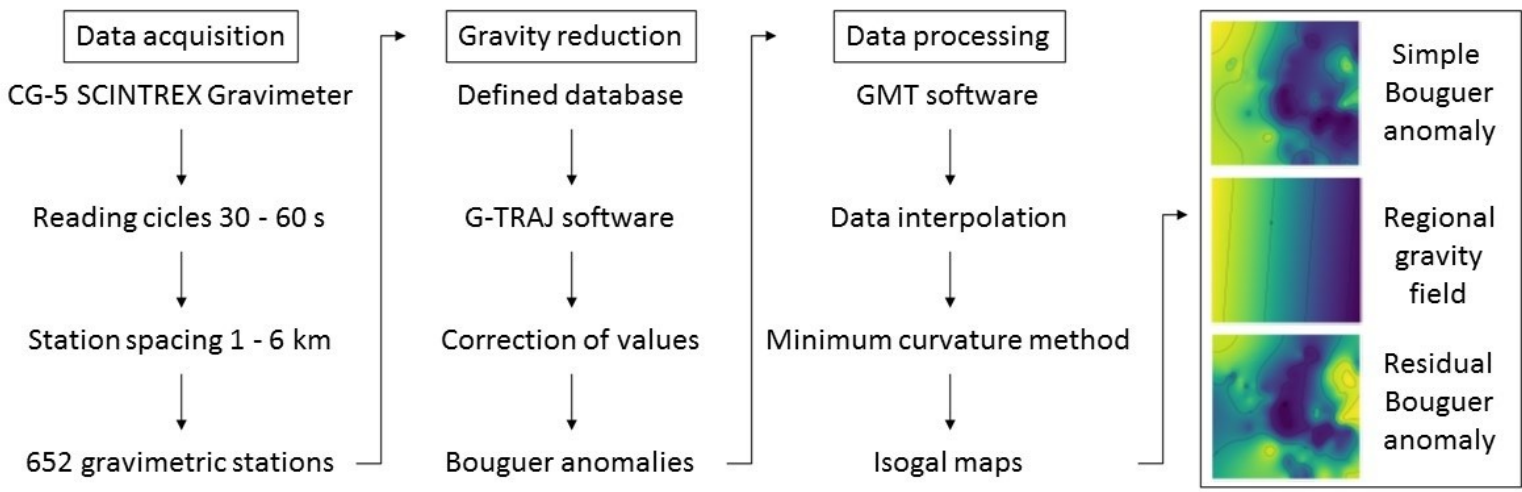

Figure 4 - Flowchart of geophysical data processing for gravity data.

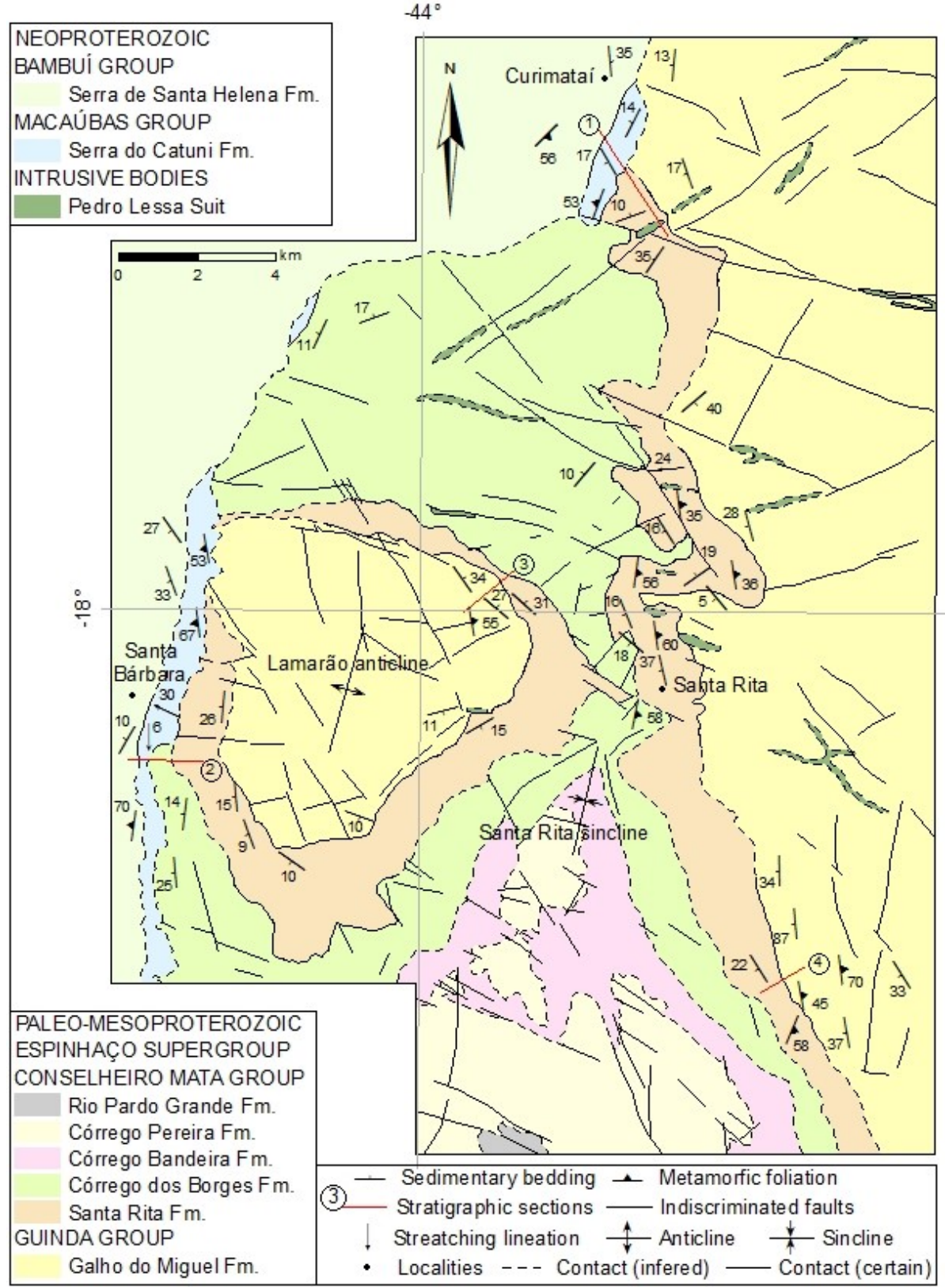

Figure 5 - Geological map based on new field data obtained in the present work, compiled from the map of Köster (1984). See location in Figure 1. 
A) SECTION 1

\begin{tabular}{|c|c|c|c|c|}
\hline Group & Formation & $\begin{array}{c}\text { Stratigraphic } \\
\text { chart }\end{array}$ & 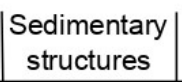 & Description \\
\hline BAMBUÍ & $\begin{array}{c}\text { Serra de } 800 \\
\text { Santa Helena }\end{array}$ & $\begin{array}{l}= \\
= \\
= \\
=\end{array}$ & $\equiv$ & $\begin{array}{l}\text { Metasiltstones and phyllites with high } \\
\text { degree of alteration, composed basically } \\
\text { of quartz and sericite, structured by plane- } \\
\text { parallel lamination and intercalated with } \\
\text { rare millimetric to centimetric horizons } \\
\text { of metaclaystones. }\end{array}$ \\
\hline
\end{tabular}

B) SECTION 2

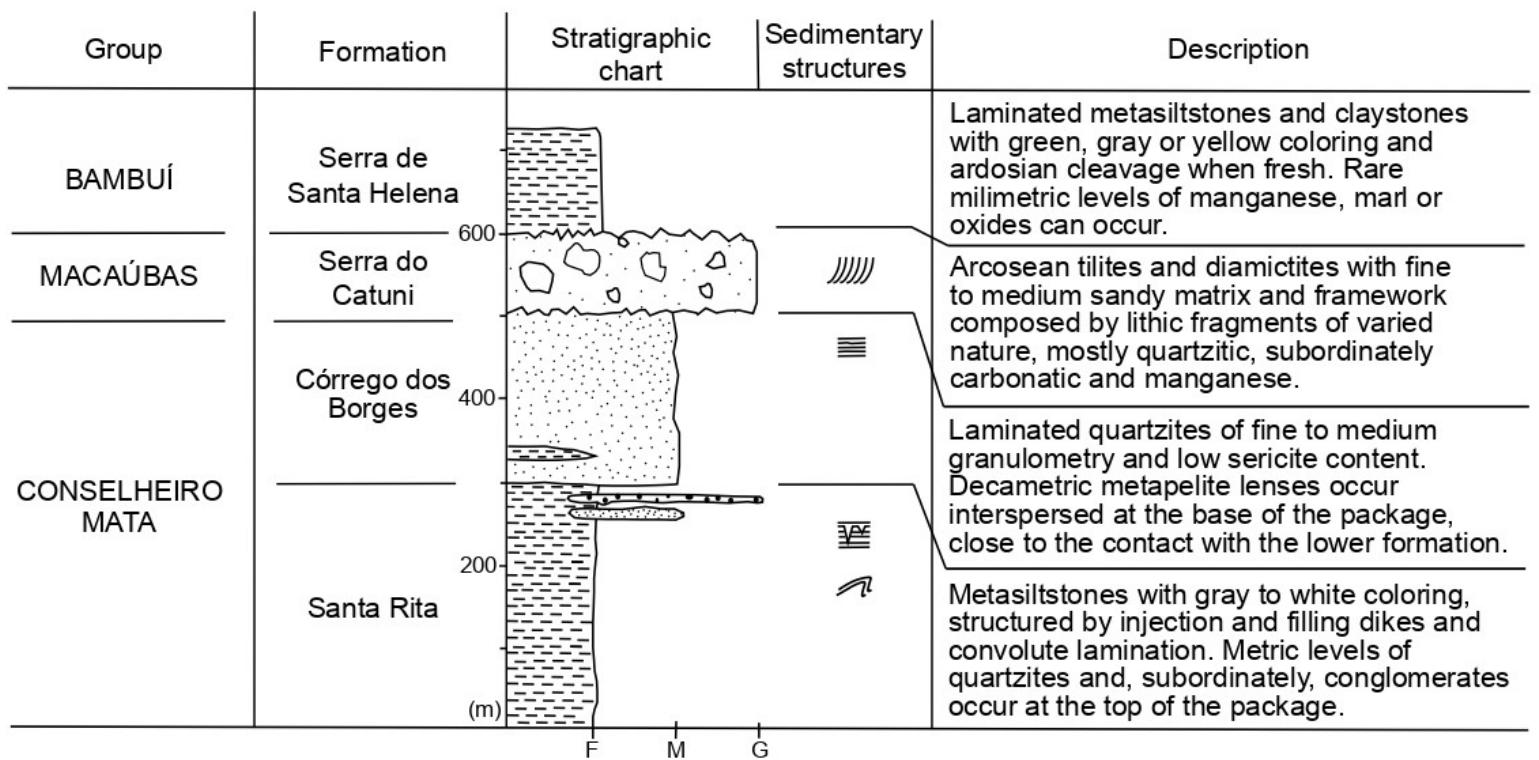

Figure 6 - Descriptions, sedimentary structures, formations and groups related to stratigraphic sections 1 and 2 . See location in Figure 5.

\section{Guinda Group}

This group, within the map of Figure 1, is represented only by the Galho do Miguel Formation. It outcrops in the eastern and centralwestern domains of the study area, defining rough and very protruding relief. This formation is essentially composed of very pure, fine granulation metarenites with high degree of textural and compositional maturity (Pflug, 1968; Schöll \& Fogaça, 1979), being rich in small to large tabular cross-bedding stratifications, which can reach 10 meters in height by tens of meters in length. 
A)

SECTION 3

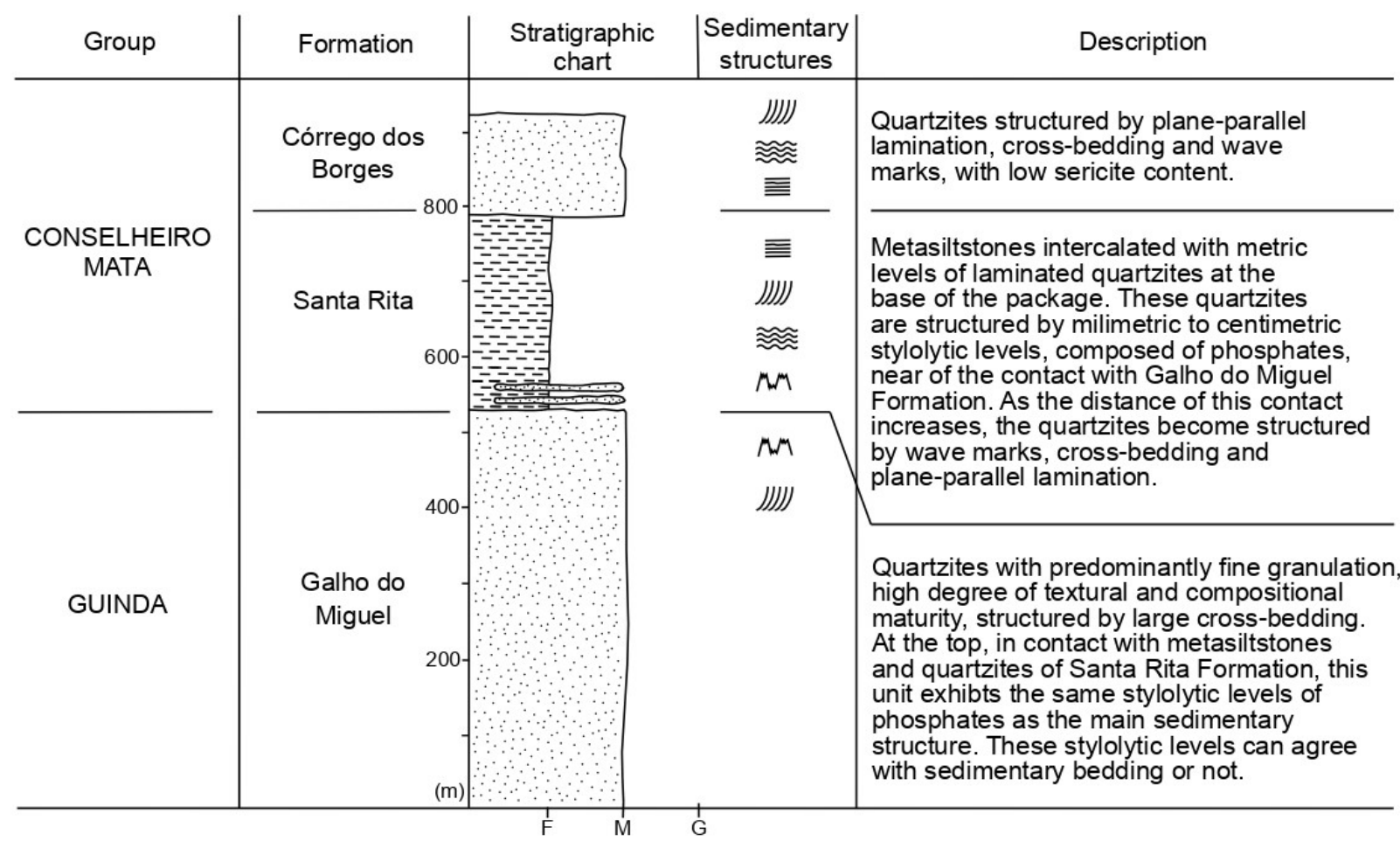

B)

SECTION 4

\begin{tabular}{|c|c|c|c|c|c|}
\hline Group & Formation & & $\begin{array}{c}\text { Stratigraphic } \\
\text { chart }\end{array}$ & $\mid \begin{array}{c}\text { Sedimentary } \\
\text { structures }\end{array}$ & Description \\
\hline $\begin{array}{l}\text { CONSELHEIRO } \\
\text { MATA }\end{array}$ & Santa Rita & 400 & & $\begin{array}{l}\text { 垩 } \\
\underline{\underline{\underline{\underline{\underline{E}}}}} \\
M M\end{array}$ & $\begin{array}{l}\text { Metasiltstones, structures by injection and } \\
\text { filling dikes, intercalated with metric levels } \\
\text { of laminated quartzites. The quartzites, with } \\
\text { white coloring, are structured by centimetric } \\
\text { plane-parallel laminations and assimetric } \\
\text { wave marks. Stylolytic levels, composed of } \\
\text { blue phosphates and iron oxides, occur } \\
\text { accompanying or not the sedimentary } \\
\text { bedding. }\end{array}$ \\
\hline GUINDA & $\begin{array}{l}\text { Galho do } \\
\text { Miguel }\end{array}$ & (m) & & בנקנו & $\begin{array}{l}\text { Quartzites structured by huge cross-bedding } \\
\text { with fine granulation, white coloring and high } \\
\text { degree of textural and compositional maturity. } \\
\text { Stylolytic levels, composed by blue phosphates } \\
\text { occur at the top of the package, over an interval } \\
\text { of at least } 50 \text { meters or more. }\end{array}$ \\
\hline
\end{tabular}

Figure 7 - Descriptions, sedimentary structures, formations and groups related to stratigraphic sections 3 and 4 . See location in Figure 5.

\section{Conselheiro Mata Group}

All formations of the CMG outcrop in the central and southern parts of the study area. The alternation of predominantly pelitic versus essentially sandstone units determines a relief marked by protruding strips of quartzite interspersed with lowered bands of smooth relief.
The Santa Rita Formation consists of metasiltstones/mudstones, occasionally showing metaconglomerate lenses and metarenite layers of metric thicknesses (Fig. 6B). The contact zone with Galho do Miguel Formation consists in gradational transitions of 1 to 10 meters in thickness, between predominantly bimodal sericitic quartzites and 
greyish phyllites with quartz content, in alternating arrangements of millimetric to centimetric layers, structured by plane-parallel laminations (Fogaça, 1997). In the study area, we observed that this contact shows intercalations of metasiltstones with laminated metarenites between tabular layers of metric thickness, being common the presence of stylolitic levels containing oxides, sulfides and phosphates (lazulite) (Fig. 7). A compositional and granulometric banding from millimetric to centimetric thickness is frequent, sometimes showing small synsedimentary normal faults. Cross laminations are also common and, in places, mud cracks of tens centimetric scale can appear.

The Córrego dos Borges Formation is composed of greyish metarenites, rich in planeparallel laminations, also with crossstratifications and ripple marks (Schöll \& Fogaça, 1979). They settle in conformity on the metapelites of the Santa Rita Formation, through transitional contacts, evidenced by the intercalation of sandy layers and pelitic levels. The millimetric to centimetric plane-parallel lamination is almost a universal characteristic in the metarenites of this unit (Fig. 6B).

The Córrego da Bandeira Formation encompasses rhythmic layers, that intercalate sandy and pelitic levels of decametric thickness. Metarenites show cross-laminations.

The Córrego Pereira Formation consists of pure metarenites, sometimes containing sericite and, or feldspar. Sedimentary structures such as tabular cross-stratifications, cross-laminations and ripple marks are common in this formation.

The Rio Pardo Grande Formation assembles metarenites, metapelites and metasiltites, with dolomite lenses locally. Sedimentary structures are abundant, especially stratification flaser, lenticular bedding, ripple marks and, eventually, clastic injection dykes (Schöll \& Fogaça, 1979).

The units of the ESg are cut by basic rocks from the Pedro Lessa Suit. They comprise elongated bodies, lodged in larger lineaments that section all units outcropping in SER (Fig. 5). These bodies are easily mapped by the resulting red and clay soils that contrast with the clear and predominantly sandy soils of the rocks that fit them. The dikes of Pedro Lessa Suit cut all tectonic structures modelled in the rocks of the ESg. Almeida-Abreu \& Renger (2002) identified some dikes also cutting glaciogenic rocks of the Macaúbas Group.

\section{Macaúbas Group}

Glaciogenic rocks of the Macaúbas Group appear as narrow and discontinuous fringes along the western slope of SER (Fig. 5). Petrographically, they are similar to those described as Jequitaí Formation by Isotta et al. (1969) and the tillites of Serra do Catuni Formation described by Noce et al. (1997b). Despite the small thickness now exposed, the tillites continue for tens of kilometres on a surface with negligible variations in altitude and overlapping different formations of the ESg. These relationships reveal, therefore, the pronounced angular and erosive unconformity between the ESg units and the rocks of the Macaúbas Group. The contacts between the glaciogenic rocks and their substrate, i. e., rocks of the ESg, are often exposed and show clearly erosive surfaces. The expression of the discordant relationships between the rocks of $\mathrm{ESg}$ and those of Macaúbas Group reveals that the thickness of the tillites significantly increases in the thalweg of the drainages that flow to the west, indicating the notable erosive unconformity.

The tillites exhibit clasts of different sizes and degrees of roundness, with predominant angular to sub-angular terms of different types of quartzite, milky quartz, carbonates, metapelites (sometimes with manganese nodules) and granitoids. The clasts appear immersed in a sandy matrix containing lithic components (fragments of rocks, polycrystalline quartz and grains of carbonates), sometimes faceted or with striations aligned in an approximately east-west direction. 


\section{Bambuí Group}

The rocks of the Bambui Group only appear in the western part of the study area (Fig. 5), sometimes covering rocks from the $\mathrm{ESg}$, and sometimes covering rocks from the Macaúbas Group. This arrangement suggests a significant lapse of time between deposition of the rocks of these two groups, since before the deposition of the Bambuí Group units, the Macaúbas Group rocks were lithified and deeply eroded.

In the study area, the Bambuí group is represented exclusively by metapelites and phyllites of the Serra de Santa Helena Formation. Outcrops of rocks from this unit are rare and usually weathered. Brownish to reddish shales crop out in the drainage bed or in the ravines of hills that stand out in the relief.

\section{Structural Framework}

The structural arrangement of the study area is defined by a succession of relatively smooth anticlines and synclines, whose axes have a general north-south direction. Eventually they show culminations of brachanticlines and brachsynclines (Pflug, 1965; Dinis \& Pinheiro, 1980; Dossin et al., 1984; Kuchenbecker et al., 2015). The slight asymmetry of the folds and the associated planeaxial cleavage indicate deformation with vergence to the west. The persistence of the $\alpha S_{0}<\alpha S_{n}$ relationship in the rocks and even the conformation of the associated tectonic strata and structures make it clear that, in the study area, the folds do not have inverted flanks. The Lamarão anticline and Santa Rita syncline (Fig. 5) have periclinal terminations to the north and south, evidenced by the ellipsoidal shape of the regions where Santa Rita and Córrego da Bandeira formations emerge, respectively.

\section{Gamma spectrometry}

From the parameters presented in Table 1, around 14,000 data were processed for each channel. After completing the processing steps above mentioned (Fig. 2), the map for each channel was plotted, as well as the ternary RBG map (Fig. 8). Qualitatively, it is possible to affirm that the radiometric responses observed on the maps provide coherent information when compared to the outcropping geological units (Figs. 5 and 8). A simple quantitative evaluation parameter was made by comparing the concentration of each element (considering a relative scale "low" to "high", according to the values in Table 2) with the predominant lithologies of the respective stratigraphic units.

The areas where metapelitic units outcrop coincide with the spatial distribution of positive anomalies, given by high values of the relative scale, and which follows linear to curvilinear patterns. On the other hand, anomalies of low to intermediate values generally coincide with the areas occupied by quartzites. Consequently, the Santa Rita, Córrego Bandeira and Rio Pardo Grande formations, which have predominant meta-siltstones/-mudstones lithologies, present high $\mathrm{K}$, eTh and eU values. In the ternary RGB map, these values turn into light to cyan tones. The Serra de Santa Helena and Serra do Catuni formations have the same characteristics.

Stratigraphic units whose predominant lithology is quartzite, i. e., Galho do Miguel, Córrego dos Borges and Córrego Pereira formations, predominantly exhibit low to intermediate values of $\mathrm{K}, \mathrm{eTh}$ and eU, expressed in the ternary RGB map by purple to dark green areas, resulting in a remarkable contrast relative to the other formations.

\section{Gravity}

Figure 9 presents the results of 652 stations after all steps of processing. Bouguer anomalies varied from -116.5 to $-88.2 \mathrm{mGal}$, thus showing an amplitude of $28.3 \mathrm{mGal}$. The highest values were observed in the northwest of Serra do Cabral, while the lowest ones were concentrated in the central and southeastern part of the study area (Diamantina domain) (Fig. 9A).

The residual Bouguer anomaly highlights an amplitude of $27 \mathrm{mGal}$, in the range of -12 to $15 \mathrm{mGal}$, 

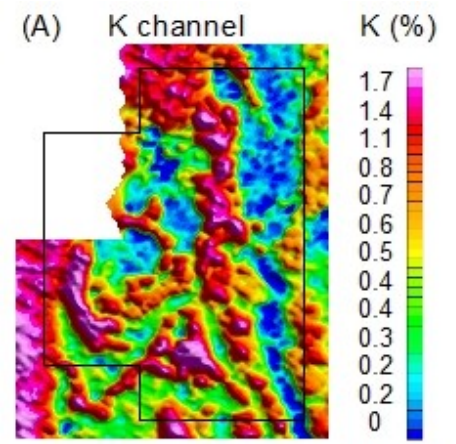

(B) Th channel

eTh (ppm)
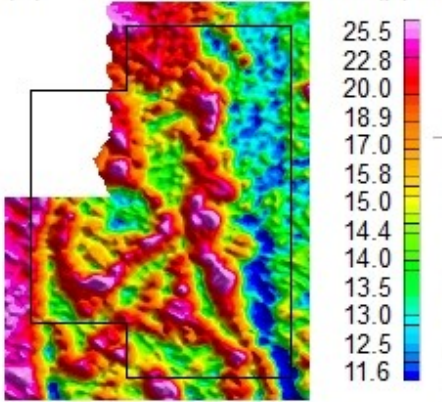

(C) U channel

$\mathrm{eU}(\mathrm{ppm})$
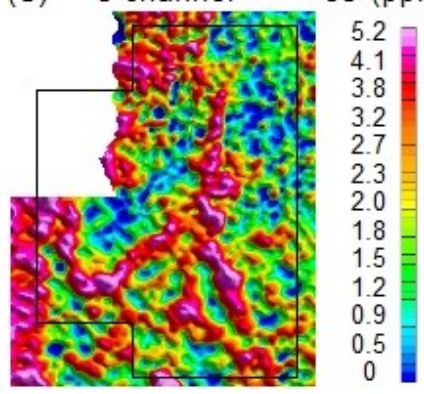

(D) Ternary Image

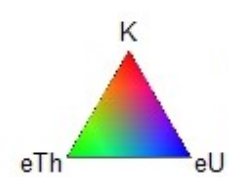
$-44^{\circ}$
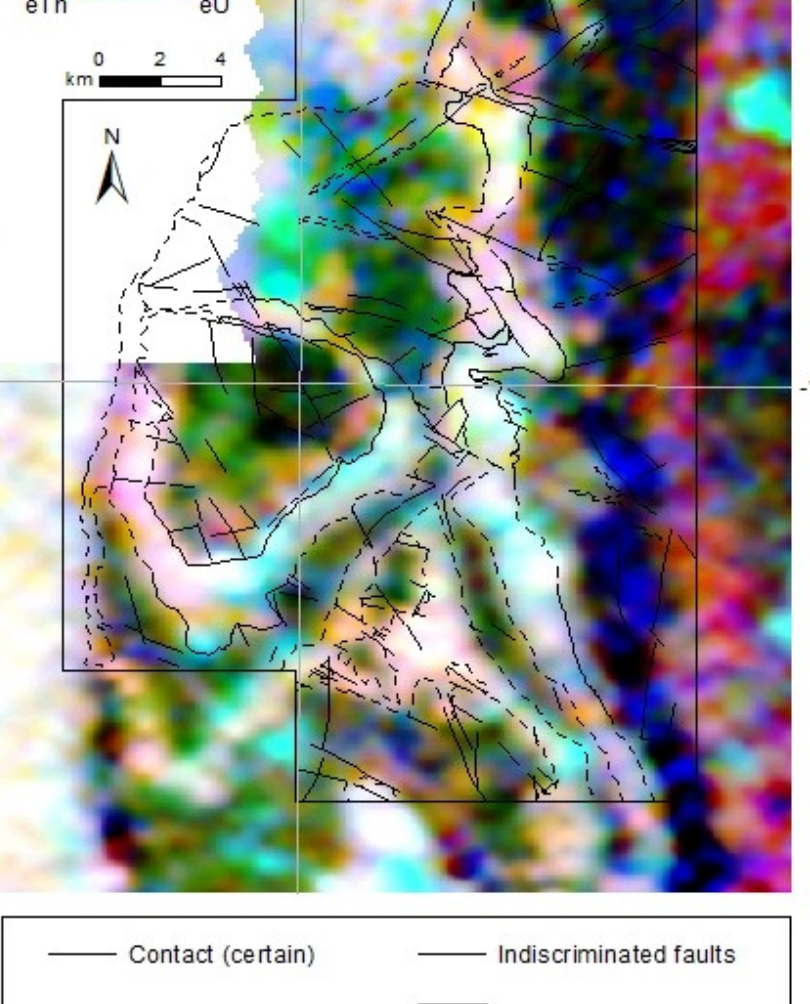

_ Indiscriminated faults

---- Contact (infered) Local study area

Figure 8 - Gamma-ray spectrometry maps: K (a), eTh (b) and eU (c) channels and ternary composite RGB image (d).

Table 2 - Gamma-ray spectrometry responses for each formation in the study area.

\begin{tabular}{|c|c|c|c|c|c|c|}
\hline \multirow[b]{2}{*}{ Group } & \multirow{2}{*}{\multicolumn{2}{|c|}{ Formation }} & \multirow[b]{2}{*}{ Lithology } & \multicolumn{3}{|c|}{ Content in } \\
\hline & & & & K_ch & eTh_ch & eU_ch \\
\hline Bambuí (B) & \multicolumn{2}{|c|}{ Serra de Santa Helena } & Metasiltstones / phyllites & $\mathrm{H}$ & $\mathrm{H}$ & $\mathrm{I}-\mathrm{H}$ \\
\hline Macaúbas (M) & \multicolumn{2}{|l|}{ Serra do Catuni } & Tillites / metadiamictites & $\mathrm{H}$ & $\mathrm{H}$ & 1 \\
\hline \multirow{5}{*}{ Conselheiro Mata } & \multicolumn{2}{|c|}{ Rio Pardo Grande (Rp) } & Metasiltstones & $\mathrm{H}$ & $\mathrm{H}$ & $\mathrm{H}$ \\
\hline & \multicolumn{2}{|c|}{ Córrego Pereira (Cp) } & Quartzites & 1 & 1 & L-I \\
\hline & \multicolumn{2}{|c|}{ Córrego Bandeira (Cba) } & Metasiltstones & $\mathrm{H}$ & $\mathrm{H}$ & $\mathrm{H}$ \\
\hline & \multicolumn{2}{|c|}{ Córrego dos Borges (Cbo) } & Quartzites & L-I & $\mathrm{I}-\mathrm{H}$ & L-I \\
\hline & \multicolumn{2}{|l|}{ Santa Rita (Sr) } & Metasiltstones & $\mathrm{H}$ & $\mathrm{H}$ & $\mathrm{H}$ \\
\hline \multirow{4}{*}{ Guinda } & \multirow{4}{*}{ Galho do Miguel } & (Gm4) & \multirow{4}{*}{ Quartzites } & $\mathrm{L}$ & 1 & $\mathrm{~L}$ \\
\hline & & (Gm3) & & $\mathrm{I}$ & $\mathrm{I}$ & 1 \\
\hline & & $(\mathrm{Gm} 2)$ & & $L$ & $L$ & L-I \\
\hline & & (Gm1) & & $\mathrm{H}$ & I & $\mathrm{I}-\mathrm{H}$ \\
\hline
\end{tabular}

Abbreviation: L - Low; I - Intermediate; $\mathrm{H}$ - High.

For K_ch - channel of Potassium: $L(0-0.45 \%), \mathrm{I}(0.45-0.8 \%)$ and $\mathrm{H}(0.8-1.7 \%)$.

For eTh_ch - channel of Thorium: L (11.6 - $14.8 \mathrm{ppm}), \mathrm{I}(14.8-19 \mathrm{ppm})$ and $\mathrm{H}(19-25.5 \mathrm{ppm})$.

For eU_ch - channel of Uranium: L $(0-1.9$ ppm), I (1.9 - $3.2 \mathrm{ppm})$ and $\mathrm{H}(3.2-5.2 \mathrm{ppm})$. 

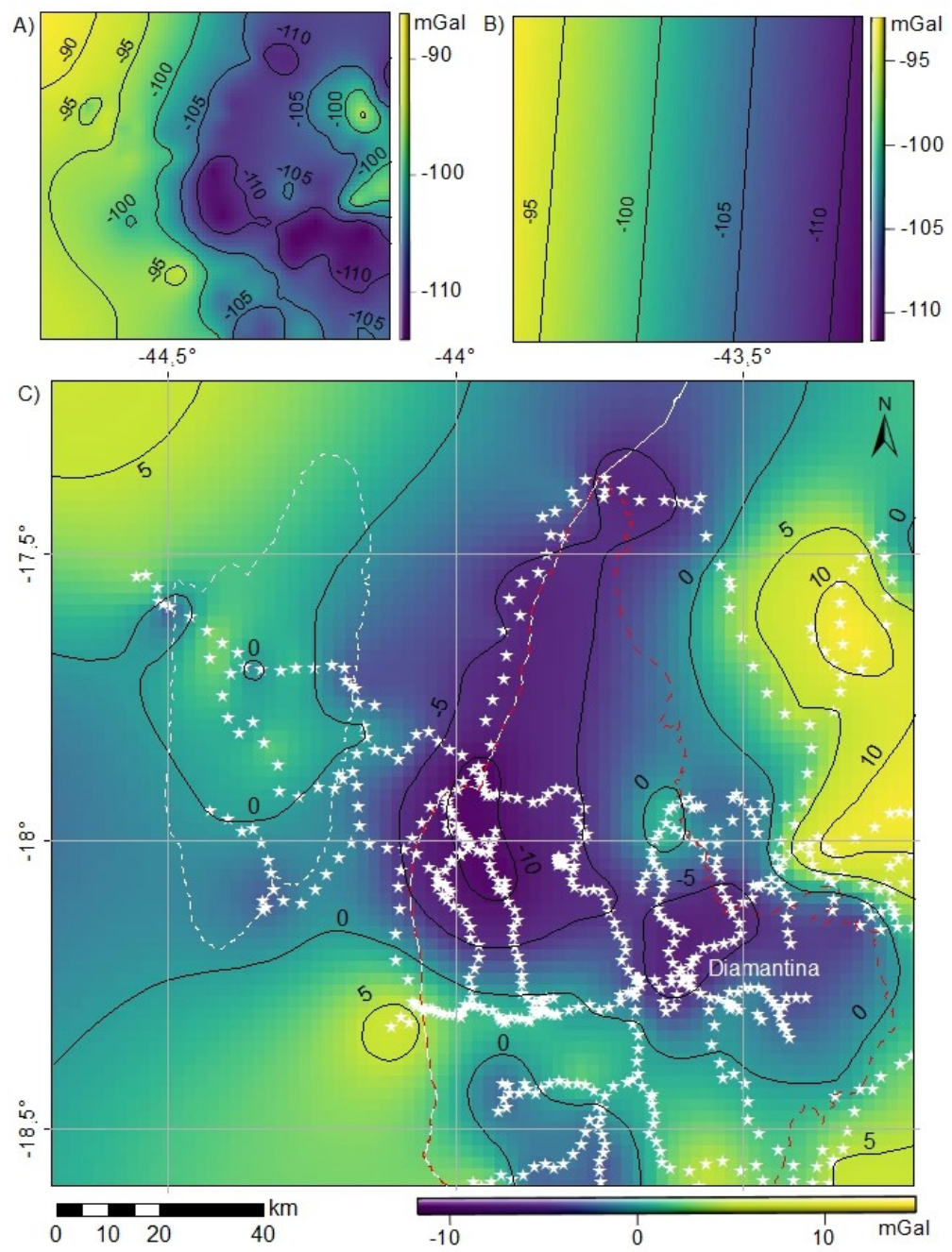

Figure 9 - A) Simple Bouguer anomaly, resulting from data interpolation of stations in Figure 3. B) Regional gravity field, obtained through a bilinear polynomial trend. C) Residual Bouguer anomaly, resulting from the subtraction between the regional gravity field and the simple Bouguer anomaly. Contour range $5 \mathrm{mGal}$. Dashed white line: Serra do Cabral. Continuous white line: southeast limit of the São Francisco Craton. Dashed red line: Southern Espinhaço Range limits. White stars: gravity stations acquired.

resulting in the predominance of negative gravity anomalies on the map (Fig. 9C). The negative anomaly concentrates in the central region of the study area, branching to NNE and ESE, towards the cities of Olhos D'água and Diamantina, respectively. Note that the areas where negative anomalies predominate roughly coincide with the SER limits (Fig. 9C). The main residual positive gravity anomaly, with values of up to $14 \mathrm{mGal}$, is located to the north of the city of São Gonçalo do Rio Preto, that is, beyond northeast orographic limit of SER.

\section{DISCUSSION}

\section{Improving surface geological settings}

Regarding the gamma-ray spectrometry data, the $\mathrm{K}$, eTh and eU channels, as well as the ternary composite RGB image (Fig. 8), fit well with the lithological types and the structural framework of the stratigraphic units observed in the field, as shown in Figures 8 and 10.

The gamma-ray spectrometric domain BM corresponds to the Serra do Catuni and Serra de Santa Helena formations (Macaúbas and Bambuí groups, respectively), where high values of all 


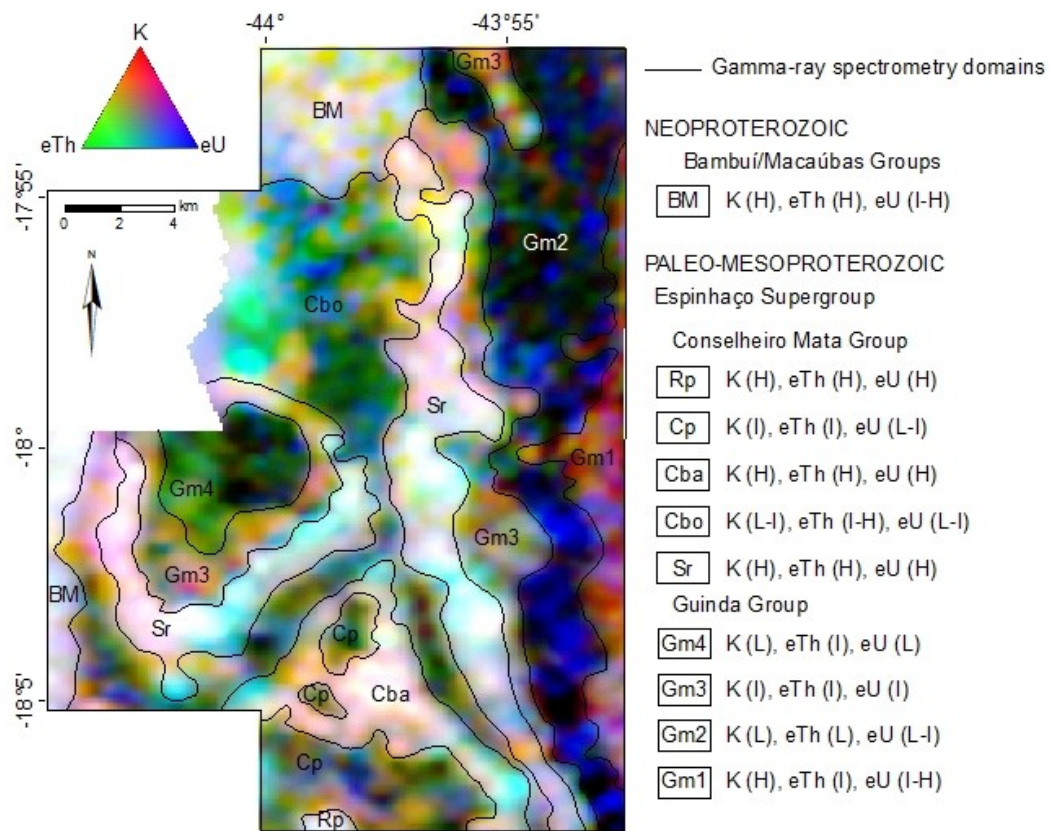

Figure 10 - Ternary RGB radiometric composition overlapped by gamma-ray spectrometry domains interpreted. $\mathrm{L}=$ low; $\mathrm{I}=$ intermediate; $\mathrm{H}=$ high.

(A)
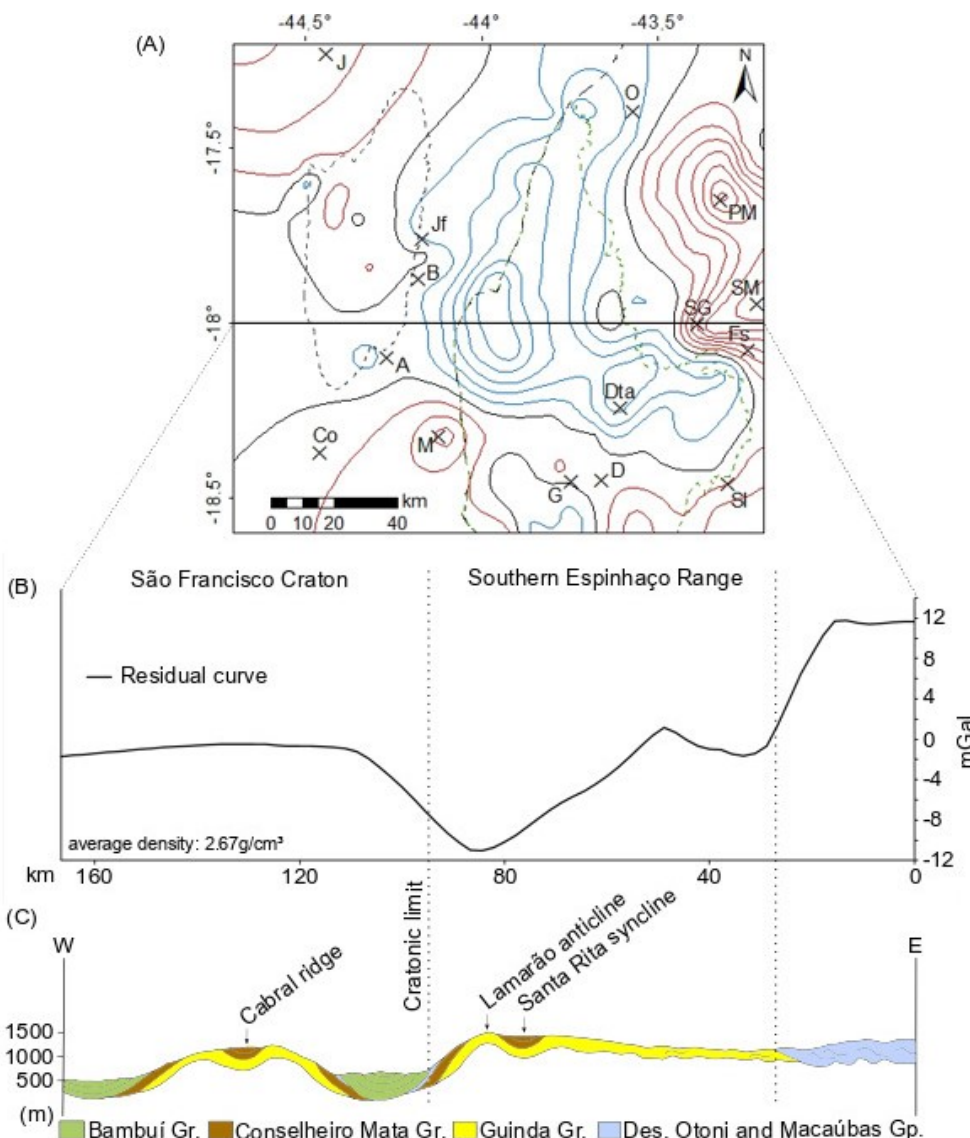

Figure 11 - (A) Contour curves of residual Bouguer anomalies. Red lines represent positive values, blue ones negative and blacks are zero. Contour range $2 \mathrm{mGal}$. Cities: same as Figure 1. (B) Residual gravity profile, (C) topographic-geological-structural profile, and its tectonic compartments. 
radioelements predominate. It does not seem possible to individualize these formations based on the ternary map. The formations of the Conselheiro Mata Group individualize themselves alternating pelitic successions versus sandstone units. While the gamma-ray spectrometric domains $\mathrm{Sr}, \mathrm{Cba}$ and Rp correspond to the metapelites of the Santa Rita, Córrego da Bandeira and Rio Pardo Grande formations, respectively, which present high values of the radioelements $\mathrm{K}, \mathrm{eTh}$ and $\mathrm{eU}$, the $\mathrm{Cbo}$ and $\mathrm{Cp}$ domains correspond to the metarenites of the Córrego dos Borges and Córrego Pereira formations, expressed by low to intermediate values of each element. The metarenites of the Galho do Miguel Formation (Guinda Group), in turn, correspond to the gamma-ray spectrometric domains $\mathrm{Gm} 1, \mathrm{Gm} 2, \mathrm{Gm} 3$ and $\mathrm{Gm} 4$.

Despite the conspicuous correlation between the limits of each domain and the geological contacts between the formations, some areas deserve attention. The Gm3 domain, characterized by intermediate values of all elements, represents the transition zone between $\mathrm{Sr}$ and $\mathrm{Gm} 2 / \mathrm{Gm} 4$ domains. This contact strip between the Santa Rita and Galho do Miguel formations, in addition to the radiometric signature of $\mathrm{Gm} 3$ domain, has distinct geological characteristics from its adjacent areas. The presence of metric layers composed of laminated metarenites with stylolitic levels, interspersed with metapelites (Fig. 7), indicates changes in the depositional and basin environments, being well marked by the peculiar radiometric signature of this domain.

The shape and distribution of gamma-ray spectrometric domains highlight the correlation between gamma-ray emission and lithologies and reflect the geometric and structural controls of the ESg supracrustal rocks in the study area. Two specific situations were observed and should be discussed: (i) the E-W displacement of the $\mathrm{Gm} 1$, $\mathrm{Gm} 2, \mathrm{Gm} 3$ and $\mathrm{Sr}$ domains on the center-east of the study area. The geological map (Fig. 5) shows this displacement only for the Santa Rita Formation. The continuity of this structure to the east, under the metarenites of the Galho do Miguel Formation, is evident through the differentiation of the $\mathrm{Gm} 1, \mathrm{Gm} 2$ and $\mathrm{Gm} 3$ domains, given by the ternary map. Féres \& Almeida-Abreu (2019) recognize similar displacements, defining morphostructural domains in the northwest region of SER based on lineaments analysis; (ii) the absence of $\mathrm{Sr}$ radiometric signature on the northern edge of the Lamarão anticline. The geological map (Fig. 5) illustrates the formations thinning in this range, where the dimensions of the outcrops may not have been large enough to express a radiometric response on the ternary map. Both situations discussed are products of a gamma-ray spectrometric alignment that clearly displaces all domains and crosses almost the entire central region of the study area. This linear structure may be the surface projection of a planar crustal structure, with E-W direction and large scale, positioned under ESg supracrustal rocks. This structure (a strike-slip fault or a simple limit between basement blocks) causes the thinning of Santa Rita Formation (and the lack of $\mathrm{Sr}$ radiometric signature) and the displacement of $\mathrm{Gm} 1, \mathrm{Gm} 2, \mathrm{Gm} 3$ and $\mathrm{Sr}$ domains. In sub vertical quartzite walls, exposed by the pervasive WNW-ESE fracture system, slickensides appear in some places, which denote strike-slip movements with dextral sense.

The geological map integrated with the gamma-ray spectrometric data highlights an ellipsoidal structural shape for the outcrops of the Santa Rita and Córrego da Bandeira formations which is evidenced by northern and southern periclinal terminations of the Lamarão anticline and Santa Rita syncline, respectively. Lopes et al. (2012) observe the same structural situation for the Córrego da Bandeira and Córrego Pereira formations, in the northwest portion of Serra do Cabral. We suggest this structuring as the result of flexural sliding associated with inter-stratum shear during edification of SER, since this is in accordance with the radial dispersion of the bedding and, mainly, by the plunge direction of the stretching lineation. The mass transport from east to west during orogenesis must be responsible for modelling these structures.

Dossin et al. (1984) report the presence of brachy-anticlines and brachy-synclines in SER, attributing the double plunge of the axes of these folds to compressive efforts of meridian direction. 
However, there are no penetrative tectonic structures that can demonstrate a compressive deformational event in the N-S direction. Therefore, the smooth N-S plunge of the fold axes can be attributed, in principle, to vertical movements of the W-E to NW-SE lineaments that cut the SER. The late to post tectonic activity of these large lineaments is evident, given that they cut through all the orogenic tectonic structures of $\mathrm{N}-\mathrm{S}$ direction and are even filled in whole or in part by basic rocks of Pedro Lessa Suit (906 $\pm 2 \mathrm{Myr}$, Machado et al., 1989).

Regarding the Lamarão anticline, the reactivation of the basement structures and their deformational influence on the covering units cannot be ruled out. Hercos (2007) recognizes thick-skinned tectonics in Serra da Água Fria (northwest of Serra do Cabral), where uplift of basement blocks generated huge folds and exposed rocks of the ESg. If the deformational process involved the basement in the study area, it is possible that blocks were individualized by thrusting faults and raised under the metasedimentary cover, thus contributing to fold generation. On the other hand, even considering thin-skinned tectonics (as suggested by AlmeidaAbreu et al., 2019), it cannot be disregarded the involvement of basal detachment thrusting faults propagating under supracrustal cover and causing the fold. Rolim et al. (1992) proposed such a deformational model for upper units of the ESg. Therefore, according to these authors, smooth and asymmetric folds would have been generated to accommodate a movement that propagated along a basal detachment thrusting fault. We believe that the association of these processes, evidenced by the fold system and the displacement of gammaray spectrometry domains described, was responsible to model the structural arrangement of the northwest part of the SER.

\section{Subsurface geological settings}

The residual Bouguer anomaly map (Fig. 9C) shows a gravity compartmentation defined by a central negative gravity anomaly (CNA) surrounded by positive gravity anomalies in the study area. The negative anomaly makes up a relatively narrow strip, which extends from the northeast to the central area of the map, where it inflects to the southeast until reaching the area of the city of Diamantina. The distribution of the CNA generally coincides with the SER contour line, except on the western border, where the CNA crosses the supposed boundary between the SER and the São Francisco Craton.

The CNA conforms to the main axis of SER, indicating, therefore, the residual metasedimentary coverage of the Espinhaço Basin with a greater thickness than the surrounding areas. It can be seen, in Figures 9 and 11, which one had already been recognized through surface geology by Almeida-Abreu et al. (1992) and Souza \& Alkmim (1995), as well as by gravity data (Blitzkow et al., 1979). The CNA encompasses the western surroundings of the Lamarão anticline. As illustrated by Figure 1, the cover rocks of SER western edge and Serra do Cabral are structured in the form of broad synclines and anticlines, smooth and open (Pflug, 1965; Dinis \& Pinheiro, 1980; Köster, 1984). Since the CNA is understood as a deep gutter that houses the nucleus of the precursor basin of the CMG, it must also have contributed to accommodate the deformation that sculpted the regional fold system.

The residual gravity profile plotted in Figure $11 \mathrm{~B}$, resultant from the interpolation of all gravity stations raised by the residual Bouguer anomaly map, establishes the geometries in depth of the gravity anomalies. The CNA has its perigee under the ridge of Lamarão anticline. The inversely proportional correlation between (i) gravity signal on the subsurface and (ii) topography and structural arrangement on the surface (Fig. 11B and 11C, respectively) suggests an isostatic compensation process. In this area, tectonophysics shows that the thickened crust has a low thermal age, causing the maximum depth of the mantle limit.

One of the positive gravity anomalies defines a north-south strip beyond the eastern contour line of SER, especially in the northeast, where it reaches up to $14 \mathrm{mGal}$ on the basalt rocks of the Planalto de Minas Formation in the vicinity of the 
homonymous village (Figs. 9 and 11). The second positive gravity anomaly is also expressed in the northwest corner of the area addressed beyond the limits of Serra do Cabral, towards Serra da Água Fria. This anomaly may be related to the high basement reported by Romeiro-Silva \& Zalán (2005) and Hercos et al. (2007). Another positive local anomaly also appears on the southwest edge of the SER (Fig. 9), in the area of the city of Monjolos, which may indicate a basement high, where the sedimentary cover of the Bambuí Group sits directly on the rocks of the cratonic basement, as suggested by Souza \& Alkmim (1995).

In surface geology (Fig. 11C), coverings of the Paleo-/Mesoproterozoic and the Neoproterozoic, respectively, of the Espinhaço Supergroup and Bambuí Group exhibit a pronounced gravity contrast with the basaltic rocks of continental volcanism from the pre-rift phase of the Espinhaço Basin that make up the Desembargador Otoni Group (Chula et al., 1996; Almeida-Abreu \& Renger, 2007).

The distribution pattern of residual gravity anomalies along the profile (Fig. 11) is consistent with the regional tectonic compartmentation. From west to east, residual Bouguer anomaly values in the cratonic domain remain close to zero at Serra do Cabral. As the cratonic limit approaches, the residual Bouguer anomaly values decrease sharply, reaching the gravity minimum close to -12 $\mathrm{mGal}$ under the Lamarão anticline. From this point on, residual anomalies resume a gradual rise curve until reaching values close to zero. After overcoming the eastern border of SER, in the contact between the Guinda Group and rocks of the Desembargador Otoni and Macaúbas Groups, as well as rocks of the Archean and Paleoproterozoic basement (e.g. granitoids of the Rio Itanguá Batholit, Grochowski et al., 2019), the residual anomalies reach positive values and increase sharply, reaching values of up to $12 \mathrm{mGal}$.

The gravity expression to the west of SER passing through Serra do Cabral suggests a progressive reduction of sedimentary coverings over the São Francisco Craton, especially in the northwest of the study area, i.e., towards Serra da Água Fria. Souza \& Alkmim (1995) identify a set of ups and downs of the basement in the Serra do Cabral region. Seismic reflection data supported by deep stratigraphic boreholes (Romeiro-Silva \& Zalán, 2005) revealed the presence of a somewhat deep basin over the São Francisco Craton that projects from the Brasília belt to the east. They also revealed that this basin quickly becomes shallower towards Serra da Água Fria (Jequitaí area, Fig. 11A). Furthermore, the reflectors demonstrated angular and erosive unconformities among the rocks of the Macaúbas Group with the subjacent Mesoproterozoic units of the Brasília belt, as well as with the overlying units of the Bambuí Group. Hence, the presence of the Pirapora Aulacogen reported by Souza \& Alkmim (1995), Alkmim \& Cruz (2005), Alkmim et al. (2007) and Hercos et al. (2007), as an E-W graben installed in the cratonic basement, should not have a genetic link with the SER, since the gravity high denotes an elevation of the basement sectioning its connection with the main axis of the SER.

Negative anomalies advance beyond the western orographic limit of SER (Figs. 9 and 11), and as the rocks that make up the Serra do Cabral edifice belong to the Espinhaço Supergroup, it demonstrates that the limit of the Espinhaço basin rests on the cratonic domain. In another perspective, it can be considered that the limit of the São Francisco Craton is actually located along the eastern limit of the SER orographic edifice. Almeida-Abreu et al. (2019) observed, through airborne magnetic data, that the major structural lineaments of the cratonic area integrate with those of the SER basement itself, which suddenly disappear in contact with the eastern adjacent block (i.e., with the crustal block that supports marine rocks of the ESg). This proposal is also a support in the perspective of the Guinda Group bringing together units from an extensive and wide alluvial plain adjacent to the Espinhaço marine basin (Almeida-Abreu \& Renger, 2007). In addition, Miranda et al. (2018) argue that syn-sedimentary kimberlitic intrusions occur in the SopaBrumadinho Formation (Guinda Group), showing, therefore, that this alluvial plain is located on the edge of the cratonic area. 


\section{Synthesis of geological evolution}

The integration of surface geological data with geophysical data allows formulating a critical analysis about the geological evolution of the northern termination of the SER and adjacent areas.

Within the SER orographic limits, the predominant negative gravity anomalies indicate the sedimentary piles of the Guinda and Conselheiro Mata groups, while the expression of gravity data in the vicinity of the SER shows that the units of the Macaúbas and Bambuí groups add up to relatively small thicknesses (Figs. 1, 9, and 11). The Guinda Group occupies mainly the eastern part of the mountain range and expresses small negative anomalies, reflecting the relatively small thickness of its units, which add up to just over a thousand meters (Almeida-Abreu, 1993) or a few thousand meters (Schöll \& Fogaça, 1979). On the other hand, the characterization of the narrow and relatively deep trough that accommodated the Conselheiro Mata Group is well marked by an expressive negative anomaly that occupies the west of SER, highlighting its depocenter from the Lamarão anticline, to the north of Conselheiro Mata, as a deep gutter that houses the nucleus of the precursor CMG basin (Figs. 1, 9, and 11).

The basin that accommodated the Conselheiro Mata Group displays sedimentary feed on both sides and its sedimentary deposits do not show characteristics of a rift environment, which goes against the proposal of Santos et al. (2015). Furthermore, the supposed resumption of the 1.2 Gyr rifting of the crustal extension responsible for opening the Espinhaço Basin at 1.7 Gyr is unsustainable, given that clasts from the Rio Pardo Grande Formation (metapelites with manganese) are seen in the Macaúbas Group tillites ( 1.0 Gyr) and, in addition, the tectonic structures modelled in CMG rocks are cut by post tectonic faults, filled with basaltic rocks from Pedro Lessa Suit (906 \pm 2 Myr, Machado et al., 1989). Because the CMG basin was established on the outer (western) part of the orogenic belt and shows sedimentation age still in the Mesoproterozoic ( 1.2 Gyr, Santos et al., 2015), it may be a foredeep basin as proposed by AlmeidaAbreu et al. (2001).
The strong gravity anomaly in the northeast of the study area exalts the presence of basaltic rocks from the Desembargador Otoni Group of ESg (Almeida-Abreu \& Renger, 2007). The gravity signal is well marked even in areas now covered by rhythmites of the Macaúbas Group and, or quaternary coverings that form the wide plateaus of the region. The positive gravity anomalies addressed beyond the western limit of SER, in the northwest corner of Serra do Cabral and in the city of Monjolos, represent blocks of the cratonic basement reported by Romeiro-Silva \& Zalán (2005), Hercos et al. (2007) and Souza \& Alkmim (1995). These nucleated basement highs, resulted from the inversion of normal faults, are responsible for the thinning of the supracrustal coverings in these areas.

The southern part of the study area highlights the structural high of Gouveia and the sudden thinning of the Guinda and Conselheiro Mata groups (Figs. 9 and 11). The gravity integration with another 300 stations in the south and east of the study area (work in progress) should clarify how the units of these groups are distributed to the southern part of SER. The compartmentation of the deformation just does not meet the increase in strain to the east, as the south-central part of SER experienced a very strong deformation responsible for the building of the thrust belt reported by Herrgesell \& Pflug (1986) and Almeida-Abreu (1993). Therefore, the gravimetry of this part of SER should mainly reflect the tectonic stacking of the ESg units and the subsequent denudation of the most mobile region of the orogenic belt.

Assuming that the cratonic limit is located along the western limit of the SER orographic line, the surface geology and gravimetry shows that the ESg units enter and settle directly on the São Francisco Craton. However, it can be argued, based on the common tectonic structure of the cratonic rocks and the basement of the SER (Almeida-Abreu et al., 2019), that the cratonic limit is, in fact, along the eastern edge of the mountain range orographic limit. 


\section{CONCLUSION}

The integration between semi-detail and regional scale geological maps with gamma-spectrometric data and field gravity data represents a pioneering work for the northern part of SER and adjacent areas. The acquired gravity data proved to be valuable for reinforcing the surface geology data represented in the available geological maps and also, above all, for enlightening the characterization of the basins and the geological evolution of the Precambrian units exposed in the study area.

The airborne data proved to be valuable for the refinement of the geological cartography of the northwest area of SER, since the results of the gamma-ray spectrometry processing highlight the disappearance of the radiometric signature of the Santa Rita Formation on the north edge of the Lamarão anticline. In addition, the Gm3 gamma-ray spectrometry domain can be treated in more detail in order to better qualify its petrographic and stratigraphic relationships with the depositional environment in the context of the evolution of the Espinhaço basin.

Certainly, the superposition of other ground geophysical methods, especially magnetotellurics and seismic reflection, will provide important information for the refinement of the knowledge of the SER regional geology. The first, to characterize the structure of the crustal section, as well as to individualize the different crustal blocks. The second, to materialize the large and meso-scale orogenic tectonic structures in subsurface, as well as to typify the tectonic style.

\section{ACKNOWLEDGEMENTS}

The authors express thanks to CODEMIG, for providing aerogeophysical data, and to " $P E G B r-$ Pool of geophysical equipment at the National Observatory", for the loan of gravimeter and technical support for the acquisition of gravity data, especially to Alcides A. dos Santos, Sérgio Luiz Fontes and Ítalo Maurício. The authors would also like to thank fellow professors Lúcio M. S. Fraga and José Maria Leal and undergraduate students André Senna, Vinícius do Amaral Azevedo and Sri Ratna Oliveira for their support in field campaigns. W.M.L.F. expresses thanks to UFVJM for providing the masters scholarship.

Brazilian Journal of Geophysics, 39(1),2021

\section{REFERENCES}

ALKMIM FF \& CRUZ SCP. 2005. Cratógenos, aulacógenos, orógenos e suas interações: $O$ caso do Cráton do São Francisco-Congo e sistemas brasilianos/pan-africanos adjacentes. Proceedings of the $3^{\circ}$ Simpósio sobre o Cráton do São Francisco. p. 185-187.

ALKMIM FF, PEDROSA-SOARES AC, NOCE CM, CRUZ SCP. 2007. Sobre a evolução tectônica do Orógeno Araçuaí-Congo ocidental. Geonomos 15(1): 25-43.

ALMEIDA FFM. 1977. O Cráton do São Francisco. Revista Brasileira de Geociências, 7: 349-364.

ALMEIDA-ABREU PA \& PFLUG R. 1994. The Geodynamic Evolution of the Southern Serra do Espinhaço, Minas Gerais, Brazil. Zbl. Geol., H1/2: p. 21-44.

ALMEIDA-ABREU PA \& RENGER FE. 2002. Serra do Espinhaço Meridional: um orógeno de colisão do mesoproterozoico. Rev. Bras. Geoc., 32(1): 1-14.

ALMEIDA-ABREU PA \& RENGER FE. 2007. Stratigraphie und Fazies der südlichen Serra do Espinhaço, MG, Brasilien. ZDGG. 158: 9-29. Stuttgart, Alemanha.

ALMEIDA-ABREU PA, FÉRES WML, MIRANDA RF. 2019. Tectônica colisional da Serra do Espinhaço Meridional: padrão estrutural distinto dos blocos tectônicos amalgamados. Proceedings of the XVII SNET. Bento Gonçalves, Brazil.

ALMEIDA-ABREU PA, PFLUG $R$ \& SCHORSCHER JHD. 1992. Cover/basement relationships in the Southern Serra do Espinhaço, Minas Gerais. Zbl. Geol. Paläont 6: 1749-1760.

ALMEIDA-ABREU PA, QUEIROZ WP, ROSIĖRE CA, RENGER FE. 2001. A bacia foredeep do Orógeno Espinhaço da Serra do Espinhaço Meridional em Minas Gerais. Proceedings of the VIII SNET, Recife, Brazil.

ALMEIDA-ABREU PA. 1993. A Evolução Geodinâmica da Serra do Espinhaço Meridional, Minas Gerais, Brazil. Ph. D. Thesis, Univ. Freiburg, Freiburg, Germany, $150 \mathrm{p}$.

ALMEIDA-ABREU PA. 1995. O Supergrupo Espinhaço da Serra do Espinhaço Meridional Minas Gerais: o rifte, a bacia e o orógeno. Geonomos 3(1): 1-18. 
BARBOSA O. 1951. Contribuição à origem do diamante em Diamantina, Minas Gerais. DNPM/DGM. Bol. 136: 1-36. Rio de Janeiro.

BLITZKOW D, GASPARINI P, SÁ NC, MANTOVANI MSM. 1979. Crustal structure of southeastern Minas Gerais, Brazil, deduced from gravity measurements. Rev. Bras. de Geoc. 9(3): 39-43.

CHEMALE JR F, DUSSIN IA, ALKMIM FF, MARTINS MS, QUEIROGA G, ARMSTRONG R, SANTOS MN. 2012. Unravelling a Proterozoic basin history through detrital zircon geochronology: The case of the Espinhaço Supergroup, Minas Gerais, Brazil. Gondwana Research (22): 200 - 206.

CHULA AMD, KNAUER LG, ALMEIDA-ABREU PA. 1996. Estratigrafia do Supergrupo Espinhaço na região de Planalto de Minas, Diamantina - MG. Geonomos. v. 3(2): 69-81.

D'AGRELA-FILHO MS \& CORDANI UG. 2017. The paleomagnetic record of the São FranciscoCongo Craton. In: Heilbron $M$ et al (eds) São Francisco Craton, Tectonic genealogy of a miniature continent. Ed. Springer. P. 305-320.

D'AGRELLA-FILHO MS, PACCA IG, TEIXEIRA W, ONSTOTT TC, RENNE PR. 1990. Paleomagnetic evidence for the evolution of Meso- to Neoproterozoic rocks in central-eastern Brazil. Palaeog., Palaeoclim., Palaeoec., 80: 255-265.

DERBY OA. 1906. The Serra do Espinhaço. J. Geol., v. 14, p. 394-401.

DINIS HB \& PINHEIRO RM. 1980. Projeto Mapeamento Geológico do Espinhaço Meridional. Relatório de Quadrículas - Conselheiro Mata (SE23-Z-A-III-3SO). UFMG. C. Geol. Eschwege. Diamantina, Brazil. 58p.

DOSSIN IA, DOSSIN TM, CHAVES MLSC. 1990. Compartimentação estratigráfica do Supergrupo Espinhaço em Minas Gerais - os grupos Diamantina e Conselheiro Mata. Revista Brasileira de Geociências. 20 (1-4): 178-186.

DOSSIN IA, UHLEIN A \& DOSSIN TM. 1984. Geologia da faixa móvel Espinhaço em sua porção Meridional - MG. Proceedings of the XXXIII Cong. Bras. de Geol. Rio de Janeiro, Brazil.
DUPONT H. 1995. O Grupo Conselheiro Mata no seu quadro paleogeográfico e estratigráfico. In: Proceedings of the $8^{\circ}$ Simp. de Geol. de MG. 13: 9-10. Diamantina, Brazil.

DUSSIN IA \& DUSSIN TM. 1995. Supergrupo Espinhaço: modelo de evolução geodinâmica. Geonomos. v. 3: 19-26.

ESCHWEGE WL. 1822. Geognostissches Gemälde von Brasilien und wahrscheinliches Muttergestein der Diamanten. Weimar, Landes Industrie Comptoir, 44p.

FÉRES WML \& ALMEIDA-ABREU PA. 2019. Uma abordagem preliminar dos lineamentos estruturais da região noroeste da Serra do Espinhaço Meridional. Proceedings of the XIX SBSR. Santos, Brazil.

FOGAÇA ACC, ALMEIDA-ABREU PA, SCHORSCHER HD. 1984. Estratigrafia da sequência supracrustal arqueana da porção mediana-central da Serra do Espinhaço Meridional, Minas Gerais. Proceedings of the XXXIII Cong. Br. Geol. 6: 2654-2667. Rio de Janeiro.

FOGAÇA ACC. 1997. Geologia da Folha Diamantina, Minas Gerais. In: GROSSI-SAD JH, LOBATO LM, PEDROSA-SOARES AC \& SOARES-FILHO BS. Projeto Espinhaço em CDROM (textos, mapas e anexos). CODEMIG. p. 1575-1665.

FRAGA LMS. 2013. Análise estratigráfica do Grupo Macaúbas no domínio meridional da Serra do Espinhaço, Minas Gerais. Tese de doutorado. Universidade Federal de Minas Gerais. Belo Horizonte. 203 p.

GIESE P \& SCHÜTTE KG. 1980. Resultados das medidas de sísmica de refração a leste da Serra do Espinhaço, MG, Brasil. Ed. Zeil W. 7: 44-50.

GROCHOWSKI J, KUCHENBECKER $M$, BARBUENA D, NOVO TA. 2019. Integrating geological and airborne geophysical data to review the cartography of Rio Itanguá Batholith, Araçuaí Orogen, Brazil. Brazilian Journal of Geology. v. 49. n. 3.

HAGEDORN MG, ALMEIDA-ABREU PA, RENGER FE. 2003. Principais eventos magmáticos a leste do Cráton São Francisco, norte de Minas Gerais (MG): caracterização e 
implicações. Proceedings of the IX SNET. p. 9194. Búzios, Brazil.

HEILBRON M, CORDANI UG, ALKMIM FF. 2017. São Francisco Craton, Eastern Brazil - Tectonic Genealogy of a Miniature Continent. Ed. Springer. $331 \mathrm{pp}$.

HERCOS CM, MARTINS-NETO MA \& FILHO AD. 2007. Arcabouço estrutural da Bacia do São Francisco nos arredores da Serra da Água Fria (MG), a partir da integração de dados de superfície e subsuperfície. Rev. Bras. de Geoc. 38(2): 197-212.

HERRGESELL G \& PFLUG R. 1986. The Thrust Belt of the Southern Serra do Espinhaço, Minas Gerais, Brazil. Zbl. Geol. Paläont. Teil I. 9/10: 1405-1414. Stuttgart.

HOPPE A. 1986. Geodynamic evolution of an Early to Mid-Proterozoic mountain range: The Serra do Espinhaço, central-eastern Brazil. Geocongr. '86, 21st Bienn. Congr. Geol. S. Africa, Ext. Abstr: 307-309. Joannesburg.

ISOTTA CAL, ROCHA-CAMPOS AC, YOSHIDA R. 1969. Striated pavement of the upper Precambrian glaciation in Brazil. Nature, 222: 466-468.

KARFUNKEL J \& HOPPE A. 1988. Late Proterozoic glaciation in central - eastern Brazil: Synthesis and model. Palaeog., Palaeoclim., Palaeoec., 65: 1-21.

KEAREY P, BROOKS M, HILL I. 2002. An introduction to geophysical exploration. Blackwell Publishing Company. UK. 429 pp.

KNAUER LG. 1990. Evolução geológica do Precambriano da porção centro leste da Serra do Espinhaço Meridional e metalogênese associada. Master Dissertation, UNICAMP, Campinas, SP, Brazil. 298 pp.

KÖSTER J. 1984. Geologie der nordwestlichen Serra Mineira sudöstlichen von Buenópolis (Proterozoikum, Serra do Espinhaço, MG, Brasilien). Diplomarbeit. Univ. Freiburg. 85 pp. Germany.

KUCHENBECKER M, REIS HLS, SILVA LC, COSTA RD, FRAGOSO DGC, KNAUER LG, DUSSIN IA, PEDROSA-SOARES AC. 2015. Age constraints of Espinhaço Supergroup and Bambuí
Group in eastern São Francisco Craton. Geonomos, 23(2): 14-28.

KUCHENBECKER M. 2011. Quimioestratigrafia e proveniência sedimentar da porção basal do Grupo Bambuí em Arcos (MG). Master Dissertation, Universidade Federal de Minas Gerais, Belo Horizonte, MG, Brazil. 91 pp.

LASA ENGENHARIA E PROSPECÇÕES S.A. 2009a. Levantamento aerogeofísico de Minas Gerais, Área 11A: Jaíba - Montes Claros Bocaiúva. Relatório final do levantamento e processamento de dados magnetométricos e gamaespectrométricos. Texto técnico. Belo Horizonte, MG, Brazil. 271 pp. v. 1.

LASA ENGENHARIA E PROSPECÇÕES S.A. 2009b. Levantamento aerogeofísico de Minas Gerais, Área 11B: Montezuma - Indaiabira Taiobeiras. Relatório final do levantamento e processamento de dados magnetométricos e gamaespectrométricos. Texto técnico. Belo Horizonte, MG, Brazil. 113 pp. v. 1.

LASA ENGENHARIA E PROSPECÇÕES S.A. 2009c. Levantamento aerogeofísico de Minas Gerais, Área 12: Teófilo Otoni - Governador Valadares - Caratinga. Relatório final do levantamento e processamento de dados magnetométricos e gamaespectrométricos. Texto técnico. Belo Horizonte, MG, Brazil. 166 pp. v. 1.

LOPES TC, LEITE MM, MARTINS MS, UHLEIN A, KARFUNKEL J, FONSECA A, UHLEIN GJ \& FREIRE GR. 2014. Geologia e recursos minerais da folha Serra do Cabral SE.23-X-C-V: estado de Minas Gerais, escala 1:100.000. CPRM. 72 pp.

LOPES TC, MARTINS MS, GÖTZE J, LEITE MM. 2012. As formações Córrego da Bandeira e Córrego Pereira (Grupo Conselheiro Mata, Supergrupo Espinhaço) na porção noroeste da Serra do Cabral (MG): definições das seções-tipo e contribuição ao estudo de proveniência sedimentar. Geonomos. 20(2). 44-57.

MACHADO N, SCHRANK A, ABREU FR, KNAUER LG, ALMEIDA-ABREU PA. 1989. Resultados preliminares da geocronologia $\mathrm{U} / \mathrm{Pb}$ na Serra do Espinhaço Meridional. Proceedings of the V Simpósio de Geologia de Minas Gerais. Belo Horizonte, MG, Brazil. p. 171-174. 
MARTINS-NETO MA, PEDROSA-SOARES AC \& LIMA SAA. 2001. Tectono-sedimentary evolution of sedimentary basins from Late Paleoproterozoic to Late Neoproterozoic in the São Francisco craton and Araçuaí fold belt, eastern Brazil. Sed. Geol., 141-142, 343-370.

MARTINS-NETO MA. 1998. O Supergrupo Espinhaço em Minas Gerais: registro de uma bacia rifte-sag do Paleo/Mesoproterozóico. Rev. Bras. de Geol., 48: 151-168.

MEGAFÍSICA SURVEY AEROLEVANTAMENTOS LTDA. 2001a. Levantamento aerogeofísico de Minas Gerais, Área 3: Morro do Pilar - Serro Guanhães. Relatório final do levantamento e processamento dos dados magnetométricos e gamaespectrométricos. Texto Técnico. Belo Horizonte, MG, Brazil. 58 pp. v. 1.

MEGAFÍSICA SURVEY AEROLEVANTAMENTOS LTDA. 2001b. Levantamento aerogeofísico de Minas Gerais, Área 4: São João da Chapada Datas. Relatório final do levantamento e processamento dos dados magnetométricos e gamaespectrométricos. Texto Técnico. Belo Horizonte, MG, Brazil. 58 pp. v. 1.

MIRANDA RF, BATTILANI GA \& ALMEIDA-ABREU PA. 2018. Geologia das metabrechas diamantíferas na Formação Sopa-Brumadinho, Serra do Espinhaço Meridional, MG. Proceedings of the $7^{\circ}$ Simpósio Brasileiro de Geologia do Diamante.

MORAES LJ \& GUIMARÃES D. 1930. Geologia da região diamantífera do Norte de Minas Gerais - An. Acad. Bras. Cienc., 2: 153-186.

NOCE CM. 1997a. Geologia da Folha Curimataí, Minas Gerais. In: GROSSI-SAD JH, LOBATO LM, PEDROSA-SOARES AC \& SOARES-FILHO BS. Projeto Espinhaço em CD-ROM (textos, mapas e anexos). CODEMIG. p. 1199-1250.

NOCE CM, PEDROSA-SOARES AC, GROSSISAD JH, BAARS FJ, GUIMARÃES MLV, MOURÃO MAA, OLIVEIRA MJR \& ROQUE NC. 1997b. Nova subdivisão estratigráfica regional do Grupo Macaúbas na Faixa Araçuaí. Sociedade Brasileira de Geologia, Núcleo de Minas Gerais, Boletim 14: 29-31.

PEDROSA-SOARES AC, NOCE CM, ALKMIM FF, SILVA LC, BABINSKI M, CORDANI U \& CASTAÑEDA C. 2007. Orógeno Araçuaí: síntese do conhecimento 30 anos após Almeida 1977. Geonomos, 15: 1-16.

PFLUG R \& RENGER FE. 1973. Estratigrafia e evolução geológica da margem sudeste do Cráton São Francisco. Proceedings of the $27^{\circ}$ Congresso Brasileiro de Geologia. Aracaju. 2: 5-19.

PFLUG R. 1965. A geologia da parte meridional da Serra do Espinhaço e zonas adjacentes, MG. Div. Geol. Min., Bol. 226. 55 pp. Rio de Janeiro, Brazil.

PFLUG R. 1968. Observações sobre a estratigrafia da Série Minas na região de Diamantina, Minas Gerais. In: Bol. Div. de Geol. e Min. DNPM. Notas Preliminares 142: 1-20.

PROSPECTORS AEROLEVANTAMENTOS E SISTEMAS LTDA. 2009. Levantamento aerogeofísico de Minas Gerais, Área 10: Belo Horizonte - Curvelo - Três Marias. Relatório final do levantamento e processamento dos dados magnetométricos e gamaespectrométricos. Texto Técnico. Belo Horizonte. 186 pp. v. 1.

REIS HLS. 2011. Estratigrafia e tectônica da Bacia do São Francisco na zona de emanações de gás natural do baixo Rio Indaiá (MG). Master Dissertation. UFOP. Minas Gerais, Brazil. 156 pp.

RENGER FE \& KNAUER LG. 1995. Espinhaço quo vadis? (Onde está? Aonde vai?) A evolução dos conhecimentos sobre a cordilheira do Espinhaço meridional em Minas Gerais entre 1979 e 1995. Geonomos 3(1): 31-39.

RENGER FE. 1979. Evolução dos conceitos geológicos da Serra do Espinhaço. Proceedings of the $1^{\circ}$ Simpósio de Geologia de Minas Gerais. Diamantina. p. 9-28.

ROLIM VK, COSTA SMA \& SILVA HC. 1992. Um padrão de deformação para as formações superiores do Supergrupo Espinhaço Meridional. In: Proceedings of the $37^{\circ}$ Congresso Brasileiro de Geologia. São Paulo, Brazil.

ROMANO AW, FRIEDMANN M, FERREIRA MP \& KNAUER LG. 2014. Geologia e recursos minerais da folha Corinto: estado de Minas Gerais, escala 1:100.000. CPRM.

ROMEIRO-SILVA PC \& ZALÁN PV. 2005. Contribuição da sísmica de reflexão na determinação do limite oeste do Cráton do São 
Francisco. Proceedings of the III Simpósio sobre o Cráton do São Francisco. Salvador, BA, Brazil.

SANTOS MN, CHEMALE F, DUSSIN IA, MARTINS MS, QUEIROGA G, PINTO RTR, SANTOS AN \& ARMSTRONG R. 2015. Provenance and paleogeografic reconstruction of a mesoproterozoic intracratonic sag basin (Upper Espinhaço Basin, Brazil). Sed. Geol., 318: 40-57. SCHÖLL WU \& FOGAÇA ACC. 1979. Estratigrafia da Serra do Espinhaço na Região de Diamantina (MG). In: Atas do I Simp. de Geol. de MG. Diamantina, Brazil.

W.M.L.F. and P.A.A.A. designed the project, and carried out the geological mapping field work. W.M.L.F., P.A.A.A. and W.P. carried out gravimetric surveys. W.M.L.F. was responsible for performing the geological mapping, geophysical analyses and writing the manuscript. P.A.A.A. and W.P. provided advisor regarding geological mapping and geophysics, respectively, and work in the manuscript in their areas of expertise.

Received on June 12, 2020 / Accepted on February 2, 2021

Recebido em 12 de junho de 2020 / Aceito em 2 de fevereiro de 2021

SOUZA-FILHO RG \& ALKMIM FF. 1995. A geometria do embasamento e a arquitetura da zona externa da Faixa Araçuaí na região da Serra do Cabral, MG. Proceedings of the V SNET. Gramado, RS. p. 93-94.

TELFORD WM, GELDART LP \& SHERIFF RE. 1990. Applied Geophysics. Cambridge University Press. 2nd ed., 760 pp.

UHLEIN A, TROMPETTE R \& SILVA ME. 1986. Estruturação tectônica do Supergrupo Espinhaço na região de Diamantina (MG). Revista Brasileira de Geociências, 16 (2): 212-216. 